\title{
A PARROQUIA DE SANTA MARTA DE MOREIRAS (O PEREIRO DE AGUIAR, OURENSE). PATRIMONIO HISTÓRICO-ARTÍSTICO
}

\section{Santa Marta de Moreiras parish (Pereiro de Aguiar, Ourense). Historical and artistic heritage}

\author{
Tania Pérez Pérez \\ Universidade de Vigo
}

Recibido: $31 / 03 / 20$

Aceptado: 22/06/20

\begin{abstract}
Resumo
O obxectivo deste traballo é realizar unha aproximación ao estudo da arte rural de Galicia que, sendo moi abundante, ocupa un espazo pouco cońecido a nivel nacional. A igrexa de Santa Marta de Moreiras (O Pereiro de Aguiar, Ourense) é un exemplo do románico rural galego que presenta as características deste e algunhas particularidades propias, o que fai do conxunto unha construción moi interesante dentro dos elementos que conforman este estilo.
\end{abstract}

\section{Palabras clave}

Arte románico, Ourense, Libro de Fábrica, Santa Marta de Moreiras.

\begin{abstract}
The aim of this project is to make an approach to the study of the rural art of Galicia that, being very abundant, is not widely known at a national level. The church of Santa Marta de Moreiras (O Pereiro de Aguiar, Ourense) is an example of Galician rural Romanesque architecture that presents its characteristics and some peculiarities which, as a whole, make it a very interesting construction within the elements that make up this style.
\end{abstract}

\section{Key words}

Romanesque art, Ourense, Book Factory, Santa Marta de Moreiras. 


\section{Santa Marta de Moreiras no seu contexto histórico e territorial}

A parroquia de Santa Marta de Moreiras pertence ao municipio de Pereiro de Aguiar e á provincia e diocese de Ourense. Está delimitada polas freguesías de Covas e Prexigueiró ao norte; San Xoán, San Martiño e Solveira ao sur; Calvelle, Chaudarcas e San Xoán ao leste; e Lamela, Prexigueiró, O Monte e Pazos ao oeste. Da súa xurisdición parroquial depende o anexo de San Martiño de Moreiras ${ }^{1}$.

Seguindo o estudo que Xosé Ramón e Fernández Oxea fixo sobre esta parroquia durante os anos vinte e trinta do século XX, esta constaba de dezasete núcleos de poboación ${ }^{2}$, dos cales Boeiros, Outeiro, Outeiromeao, Santa Baia, Santa Marta, San Martiño e A Venda tiñan a consideración de lugares; como aldeas aparecen Casmartiño, Caspiñón, Cimadevila, Pedraio, Penedo, Pioselo, Piñeiro e O Roupeiro; e como casais son denominados O Gruñal e Os Gozos.

Comparando varias fontes pode observarse a evolución do número total de edificios da parroquia e da súa poboación. A mediados do século XIX (1846-1850), a parroquia conta con máis de 100 casas e 754 habitantes $^{3}$; xa avanzado o século XX os censos de 1930 e 1950 ofrecen a variación destes datos: 313 edificios e 1014 habitantes e 214 edificios e 821 habitantes $^{4}$, respectivamente. As cifras para o ano 1974 só fan referencia ao número de habitantes, sendo estes $477^{5}$ en toda a parroquia e hoxe en día, os datos que achega o Instituto Galego de Estatística (IGE) ${ }^{6}$ elevan a 847 os habitantes de Santa Marta de Moreiras.

Das primeiras noticias documentais que se atopan sobre o lugar de Moreiras destaca un privilexio, escrito en latín, que data do 25 de abril do ano $1007^{7}$. Neste tempo, Afonso $V$ de León atopábase en Celanova e realizou unha doazón a favor do mosteiro de San Pedro de Rocas de trece herdades no antedito lugar de Moreiras e de tres casais en Boeiros. Posteriormente, o 16 de outubro de $1215^{8}$, a freguesía de Moreiras e outras foron concedidas con todos os seus dereitos ao mosteiro de San Estevo de Ribas de Sil polo rei Afonso IX a través dunha doazón feita no propio mosteiro.

1 "Moreiras, Santa Marta de", Gran Enciclopedia Gallega, t. XXI, Santiago de Compostela, 1974, p. 228.

2 FERNÁNDEZ OXEA, X. R. (1982): 2.

3 MADOZ, P. (1848): 596.

4 FERNÁNDEZ OXEA, X. R. (1982): 43.

5 "Moreiras, Santa Marta de", Gran Enciclopedia Gallega, t. XXI, Santiago de Compostela, 1974, p. 228.

6 INSTITUTO GALEGO DE ESTATÍSTICA. Datos do censo de poboación do ano 2007.

7 VÁZQUEZ NÚÑEZ, A. (1961): 338-342.

8 LEIRÓS FERNÁNDEZ, E. (1951): 14 (nº 156). 
O nome de Santa Marta de Moreiras continuou aparecendo en documentos durante os séculos seguintes, mais en ningún se fai referencia á construción da igrexa parroquial. De todos os xeitos, as características que presenta a igrexa permiten supor que a súa fábrica data de fins do século XIII e comezos do XIV9. A mediados do século XVI a parroquia era anexa ao bispo de Ourense, tendo a súa tenencia en 1568 o chantre Orozco. Por aquel entón, a igrexa de San Martiño de Moreiras era a igrexa matriz e pénsase que era de construción románica, aínda que se debeu destruír no século XVII e nese mesmo século se procedeu á construción da actual. Segundo Cándido $\mathrm{Cid}^{10}$, a igrexa tiña por padroeiro o mosteiro de Ribas de Sil, contaba só con nove veciños e tiña por principal alfaia un cáliz de estaño.

No termo municipal existían, ademais, tres capelas. As capelas de Santa Catalina de Cimadevila e do Socorro de Pedraio datan a súa construción no século XVII ou nun tempo moi próximo a este, xa que esta última consta que estaba en ruínas a comezos de deste século. Pero sen dúbida, a capela máis interesante é a da Nosa Señora dos Gozos. A tradición fala da súa construción e fundación grazas ao mecenado de Don Pedro Rodríguez Pantaleón nos terreos que lle foron dados o 5 de novembro de 1658 ás beiras do río Loña ${ }^{11}$.

Volvendo á igrexa de Santa Marta de Moreiras, esta inscríbese dentro dun románico tardío. O románico foi o primeiro estilo artístico en reunir a todos os pobos occidentais, e con el os costumes das súas xentes. No territorio galaico atopou un lugar propicio para o seu desenvolvemento axudado pola época de esplendor que se deu cara finais do século XI e comezos do XII. Por aquel entón, a etapa de estabilidade na que se desenvolveu o reinado de Afonso VII (o camiño xa comezara con Afonso VI) e os seus sucesores, Fernando II e Afonso IX, axudou de maneira fundamental á mellora social, política e económica. Así, Compostela converteuse nun centro de importancia estratéxica para o reino debido á figura do bispo Xelmírez, grande impulsor de edificacións relixiosas.

No eido rural aumentou a construción de igrexas como consecuencia da nova organización relixiosa (Concilio de Burgos de 1080) e da influencia da sé compostelá que, non só houbo de producir un afán de mellora das igrexas rurais galegas, se non que este desexo dos prelados, dos párrocos e dos devotos que acudían coas súas doazóns a favorecer as obras en Santiago, viuse facilitado coa dispersión dun lugar a outro de verdadeiras cuadrillas de canteiros que traballaban ás ordes dos grandes mestres da basílica compostelá ${ }^{12}$.

9 FERNÁNDEZ OXEA, X. R. (1982): 56.

10 CID, C. (1917): 356.

11 FERNÁNDEZ OXEA, X. R. (1982): 59.

12 NÚÑEZ RODRÍGUEZ, M. (1986): 7. 
A poboación rural deste tempo atopábase en núcleos moi dispersos e mal comunicados onde se foron construíndo pouco a pouco estruturas que buscaban unha harmonía coa terra e coas xentes. Xurdiron así infinidade de construcións que mantiñan as súas particularidades propias, debido a que xeralmente se edificaban en lugares onde xa existía unha veneración anterior, mais mantiñan unha liña común. A todo isto axudou a partir do século XII a reforma gregoriana, que readaptou as freguesías existentes e deu paso á construción "en masa” de templos románicos.

Estas novas edificacións valíanse dos antigos templos prerrománicos. Tanto o seu repertorio decorativo como os sillares foron materiais reempregados na construción dos templos románicos, de aí que ás veces non resulte doado diferenciar a etapa final dun período e a inicial doutro nas construcións máis antigas.

Como se pode apreciar, o románico é un estilo moi heteroxéneo dentro dun conxunto xeral que marca as pautas básicas a seguir. En Galicia e na provincia de Ourense en particular presenta unhas características diferentes das do resto peninsular.

Primeiramente, o granito é o principal material empregado na construción dos templos, feito que limita en certa medida a realización de motivos decorativos e escultóricos debido á complexidade da súa manipulación.

Por outra banda, a maior parte das capelas maiores presentan unha planta rectangular, o que contrasta coas do resto da península cuxas formas son circulares. Isto pode deberse á forte tradición visigótica que perdurou nos modelos construtivos galaicos deixando pegadas diferenciables e moi significativas. Do mesmo xeito, as cruces antefixas son un símbolo distintivo dos templos do noroeste español. Acostuman colocarse sobre o Agnus Dei no piñón da ábsida e mesmo no da nave.

\section{A igrexa de Santa Marta de Moreiras como exemplo da expansión do románico en terras ourensás}

\section{Arquitectura}

A igrexa de Santa Marta de Moreiras presenta unha planta rectangular dunha soa nave cunha ábsida tamén rectangular. A sancristía está anexa ao muro sur da cabeceira (Fig. 1). A construción foi realizada cun aparello de sillería regular sobre o que se apoia aleiro do tellado a dúas augas, mentres que o da sancristía é chan. Tanto a cuberta da nave como a da ábsida teñen no piñón dos seus extremos orientais unha cruz antefixa; a do primeiro só conserva a parte vertical da cruz, mentres que a da ábsida está situada sobre o Agnus Dei. 
A ábsida está situada na cabeceira da nave e nos muros laterais mostra unha ornamentación a destacar semellante á dos muros da igrexa, mais con diferenzas entre si.

O muro sur, ao que está anexa a sancristía, posúe uns arcos de medio punto con ornamentación vexetal no seu interior e canzorros con figuras animais e molduras na parte baixa dos arcos (Fig. 2). Esta decoración recorda á que nos mostra a fachada sur da Catedral ourensá, onde por riba do arco de descarga se sitúa un aleiro sobre o que se colocan os pequenos arcos de medio punto que descansan sobre figuras animais.

Fig. 1. Planimetría da igrexa de Santa Marta.

Fig. 2. Muro sur e fachada oriental da ábsida da igrexa de Santa Marta.
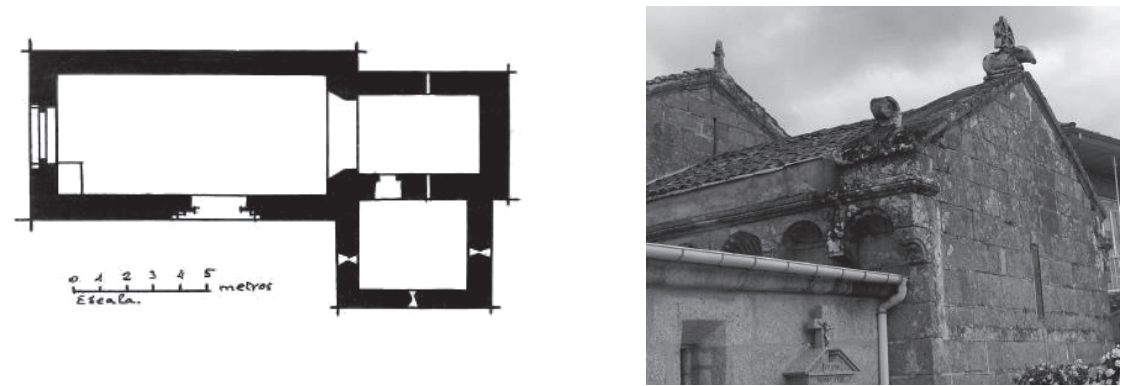

Fonte: FERNÁNDEZ OXEA, X. R. (1982): 108.

O muro norte presenta arcos de medio punto sinxelos e canzorros con decoración de rollo e simples. Na esquina esquerda aparecen uns canzorros moi singulares, xa que só son dous e están situados na parte inferior dun arco de medio punto como os do muro sur (Fig. 3).

Cara a oriente mira o muro que non posúe ningún tipo de decoración, agás una tronera $q$ se abrió en el coro o capilla maior para dar luz al altar (... $)^{13}$ no ano 1736 , cuxo marco tivo de custe dous reais ${ }^{14}$. Xa no 1853 se invisten 4 reais e 16 marabedís en tres cristais e nas puntas para poñelos na vidreira ${ }^{15}$. No piñón do tellado, como xa se dixo anteriormente, sitúase unha cruz románica antefixa sobre o Agnus Dei e unhas enormes volutas en cada esquina.

O muro da parte sur da igrexa (Fig. 4) posúe un maior número de motivos ornamentais e unha portada máis interesante que a principal. Está formada por dúas arquivoltas apuntadas que se apoian, a través dunha liña de imposta con boliñas, sobre dous pares de columnas enteiras e acobadadas con capiteis corintios deco-

13 AHDO. Santa Marta de Moreiras. Libro de Fábrica 32.10.17 (1711-1876) f. 34 r.

14 AHDO. Santa Marta de Moreiras. Libro de Fábrica 32.10 .17 (1711-1876) f. 37 r.

15 AHDO. Santa Marta de Moreiras. Libro de Fábrica 32.10 .18 (1853-1940) f. 3 r. 
rados con motivos vexetais, bolas e un colariño adxunto. Estas, á súa vez, apóianse sobre bases áticas con plintos, conservando os da parte dereita os motivos ornamentais en zigzag e figurativos. A arquivolta exterior está decorada mediante baquetóns, mentres que a interior, que tamén presenta baquetóns, insire grandes bolas entre eles.

Fig. 3. Muro norte da ábsida da igrexa de Santa Marta.

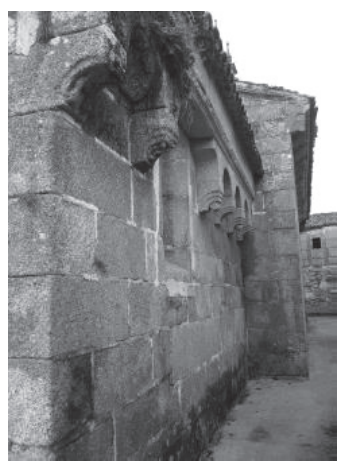

Fig. 4. Muro sur da nave da igrexa de Santa Marta.

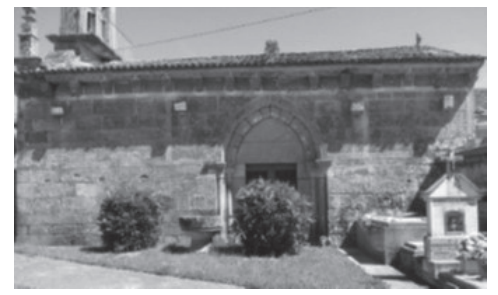

A portada é alintelada cun tímpano liso (Fig. 5) e sobre ela, no tellado, sitúase un reloxo de sol. Presenta un bo estado de conservación, rexistrándose só obras na restitución da porta de entrada. Así, no 1713 anótase un descargo dunhas táboas para as travesas das portas da igrexa, concertadas en 6 reais ${ }^{16}$, sendo o custo total da súa madeira, cravazón e do mestre que as fixo 158 reais ${ }^{17}$. En 1853 foi substituída por unha nova: (...) sesenta y ocho r doce mrs importe de hierro para visagras de la puerta nueva q dice al mediodia, clavos, plomo, unas cerraduras inglesas y demas efectos $(. . .)^{18}$.

Consérvanse catro ménsulas ao lado desta portada que deberon servir de apoio ao tellado do pórtico que a igrexa tivo tempo atrás (Fig. 6). Non se sabe con certeza en que lugar, se na portada principal ou lateral, se situaba o pórtico, pero polas marcas que hoxe en día perduran na parede e os restos das ménsulas pódese pensar que se situaría neste muro do sur.

O espazo que hai diante desta portada é maior ao que existe diante da fachada principal, polo que este é o lugar axeitado para a súa construción. Ademais, o distinto tipo de sillar que presenta o tímpano e as xambas da portada, feito que tamén sucede na da fachada principal, conducen a pensar que a porta tivera unha dobre folla que chegaría ata a parte inferior do arco permitindo unha maior luminosidade que, doutro xeito, se vería reducida polo pórtico.

16 AHDO. Santa Marta de Moreiras. Libro de Fábrica 32.10 .17 (1711-1876) f. 4 v.

17 AHDO. Santa Marta de Moreiras. Libro de Fábrica 32.10 .17 (1711-1876) f. 5 v.

18 AHDO. Santa Marta de Moreiras. Libro de Fábrica 32.10 .18 (1853-1940) f. 3 r. 
Fig. 5. Portada do muro sur da igrexa de Santa Marta.

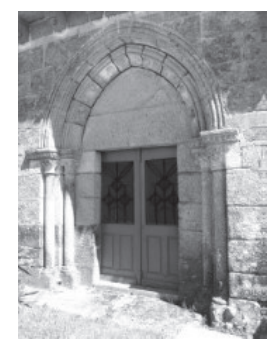

Fig. 6. Ménsulas do muro sur da igrexa de Santa Marta.

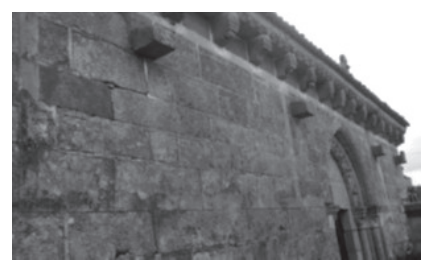

Pola parte inferior do aleiro discorre unha liña de imposta decorada con boliñas e baixo a cal se sitúan os canzorros e as métopas. Os primeiros están decorados con bolas, figuras monstruosas, animais e rolos, mentres que o espazo deixado ás métopas mostra diferenzas entre si.

A primeira métopa posúe unha ornamentación de motivos vexetais, mais as restantes ata chegar ao outro lado da portada carecen desta. A seguinte métopa decorada amosa unha figura humana disposta de xeito horizontal e a continuación os espazos están cubertos cun home xogando cun animal, flores e motivos xeométricos (Figs. 7, 8, 9).

Figs. 7-8-9. Canzorros e métopas do muro sur da igrexa de Santa Marta (de esquerda a dereita).
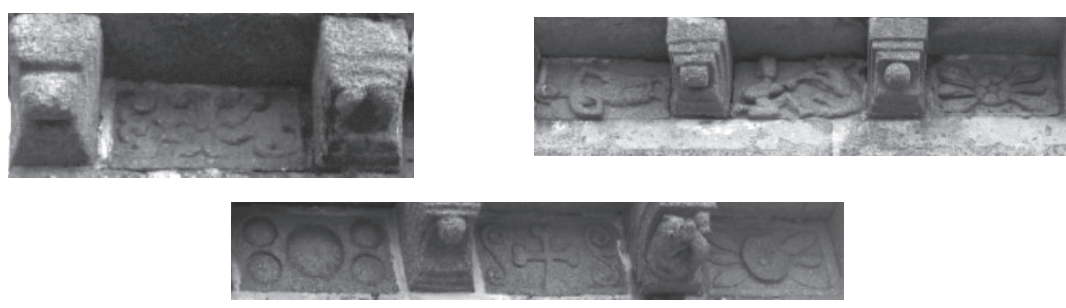

O muro norte da nave é moito máis simple que o sur, xa que non presenta ningún ornamento que non sexan o aleiro coa liña de imposta con boliñas debaixo del os canzorros decorados con molduras, bolas e rolos (Fig. 10).

Fig. 10. Muro norte da nave da igrexa de Santa Marta.

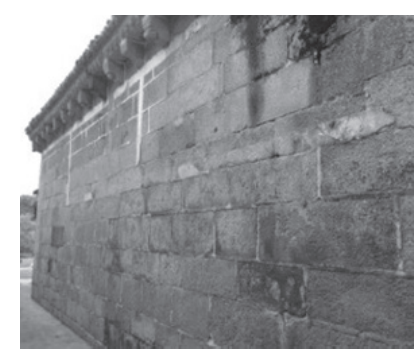


A fachada principal mira cara ao oeste. Aquí ábrese unha portada simple cun arco apuntado formado por varios baquetóns que se apoian nunha liña de imposta decorada con boliñas sobre os capiteis. A parte exterior do arco está decorada por unha arquivolta de dous fíos entre os que discorre unha liña en zigzag.

As columnas de fustes monolíticos están acobadadas e sustentan capiteis decorados con follas de acanto e un colariño adxunto. As bases sobre as que se apoian son áticas con plintos, os cales están decorados con motivos vexetais, aínda que estes non se observan na súa totalidade debido a que unha parte queda oculta polo chan.

A porta é alintelada e posúe un tímpano liso que se apoia sobre unhas ménsulas sinxelas (Fig. 11). Enriba da porta ábrese unha fiestra cunha moldura crebada nas esquinas e coroando a fachada levántase unha espadana de tres corpos de estilo barroco (Fig. 12). No seu cumio sitúase unha cruz e en cada esquina do tellado aparece un pináculo.

Fig. 11. Portada principal da igrexa de Santa Marta.

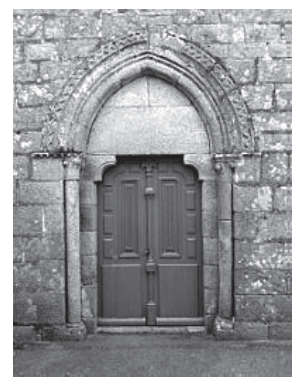

Fig. 12. Espadaña da igrexa de Santa Marta.

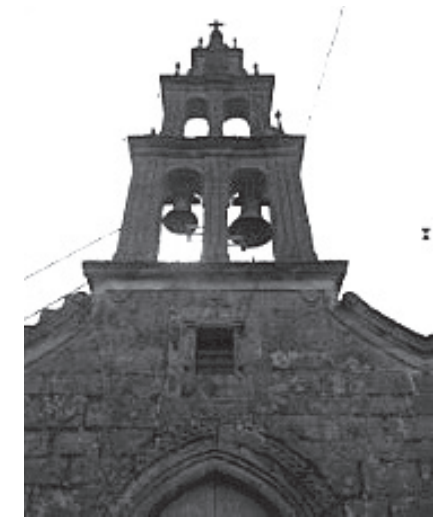

No século XVIII iníciase a construción da sancristía, que carece de motivos artísticos merecentes dun estudo, pero existe abondosa información sobre a súa construción e arranxos nos Libros de Fábrica. Foi comezada a construír no ano 1731 a costa do caudal da Fábrica e coa licenza que lle deu o bispo ao abade da freguesía ${ }^{19}$. Nos descargos dos diferentes mordomos consta un pago do 20 de marzo de dito ano de 176 reais e medio ${ }^{20}$; outro do 30 de marzo do ano seguinte de 127 reais para a fábrica da sancristía, dos que 66 foron en diñeiro e os 61 restantes na madeira empregada na obra ${ }^{21}$; e 118 reais entregados por Francisco Fernández de Casmartiño o 6 de abril do mesmo ano 22 .

19 AHDO. Santa Marta de Moreiras. Libro de Fábrica 32.10 .17 (1711-1876) f. 29 r.

20 AHDO. Santa Marta de Moreiras. Libro de Fábrica 32.10 .17 (1711-1876) f. 25 v.

21 AHDO. Santa Marta de Moreiras. Libro de Fábrica 32.10 .17 (1711-1876) f. 26 v.

22 AHDO. Santa Marta de Moreiras. Libro de Fábrica 32.10 .17 (1711-1876) f. 27 v. 
Nas contas e razón do custo total que tivo a sancristía rexístrase un importe de 1.014 reais e 3 marabedís ${ }^{23}$, sumándose outras partidas de 920 reais e 7 marabedís, faltando 93 reais e 10 marabedís que se sacaron da confraría da Magdalena ${ }^{24}$. En 1736 a sancristía aínda estaba sen pavimentar, pois neste ano sacáronse 12 reais que se lle deron a Domingo de Castro por sacar la tierra de la sacristia para sollarla ${ }^{25} \mathrm{e}$ 24 reais para pagar a dous carpinteiros $q$ sollaron la sacristia ${ }^{26}$. No ano seguinte anótanse 15 reais para acabar de pagar quarenta tercias de tablas de piso que se mercaron a Tomás Debén da Derrasa ${ }^{27}$.

En setembro de 1756 procedeuse a retellar a sancristía, recibindo José Cid, veciño do lugar da igrexa, catro reais pola súa tarefa ${ }^{28}$.

$\mathrm{Xa}$ a mediados do século XIX aparece información sobre o campanario ${ }^{29}$, mais non será ata o ano 1900 cando se leve a cabo a construcción y colocación de dos pirámides en la espadaña de la iglesia (... $)^{30}$.

$\mathrm{Xa}$ no interior da igrexa se diferencian varios espazos. O primeiro deles é a capela maior. Dá paso a ela unha grada de cantería da cal se ten constancia da súa construción entre 1905-1906 ${ }^{31}$. No Libro de Fábrica hai dúas referencias sobre as obras realizadas nesta parte da igrexa: en la continuación de las obras del presbiterio de esta iglesia de Santa Marta de Moreiras gasté las cantidades que me dio el Gobierno y 1750 pesetas mas que delante de mi peculio propio para la piedra cortada en el Chairas y la demas que tengo en el campo del Crucero (... $)^{32}$; no pudiendo llevarse a feliz término, según era mi deseo, las obras principiadas en el Presbiterio de esta iglesia de Santa Marta de Moreiras, para resarcirme de las cantidades adelantadas, mandé retirar la piedra que habia en el crucero $(\ldots)^{33}$. No muro sur ábrese unha porta que dá á sancristía. Nela atópase un caixón do cal se sabe que foi feito no ano $1738^{34}$ e que se conserva en perfecto estado, ademais da fonte que xa aparece nomeada en $1733^{35}$ e que actualmente segue en uso.

Este espazo da capela maior está cuberto por un teito de madeira a tres panos que foi reformado nos anos noventa debido ao mal estado no que se atopaba a causa das humidades. Así perdeuse o artesoado que anteriormente cubría o teito e

23 AHDO. Santa Marta de Moreiras. Libro de Fábrica 32.10.17 (1711-1876) f. 29 r.

24 AHDO. Santa Marta de Moreiras. Libro de Fábrica 32.10.17 (1711-1876) f. 29 v.

25 AHDO. Santa Marta de Moreiras. Libro de Fábrica 32.10 .17 (1711-1876) f. 34 v.

26 AHDO. Santa Marta de Moreiras. Libro de Fábrica 32.10 .17 (1711-1876) f. 34 v.

27 AHDO. Santa Marta de Moreiras. Libro de Fábrica 32.10 .17 (1711-1876) f. 35 v.

28 AHDO. Santa Marta de Moreiras. Libro de Fábrica 32.10.17 (1711-1876) f. 55 r.

29 AHDO. Santa Marta de Moreiras. Libro de Fábrica 32.10 .18 (1853-1940) f. 5 v.

30 AHDO. Santa Marta de Moreiras. Libro de Fábrica 32.10 .18 (1853-1940) f. 54 v.

31 AHDO. Santa Marta de Moreiras. Libro de Fábrica 32.10 .18 (1853-1940) f. 61 r.

32 AHDO. Santa Marta de Moreiras. Libro de Fábrica 32.10 .18 (1853-1940) f. 74 r.

33 AHDO. Santa Marta de Moreiras. Libro de Fábrica 32.10 .18 (1853-1940) f. 78 v.

34 AHDO. Santa Marta de Moreiras. Libro de Fábrica 32.10 .17 (1711-1876) f. 36 v.

35 AHDO. Santa Marta de Moreiras. Libro de Fábrica 32.10.17 (1711-1876) f. 28 v. 
que era dun gran valor artístico debido á singularidade das súas imaxes e policromía (Fig. 13).

Fig. 13. Capela maior da igrexa de Santa Marta.

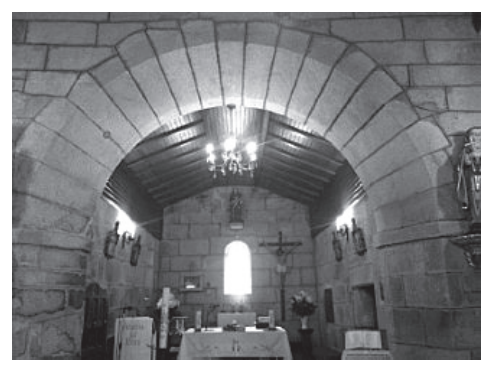

As humidades nesta zona do templo foron comúns e repetíronse de forma continua no tempo, como mostra a carta do abade pedindo licenza para acometer a restauración (Doc. 1 en Anexo).

Un arco triunfal de medio punto separa a ábsida da nave do templo. Foi construído en esviaxe para permitir a visión do altar maior. Apóiase sobre molduras e pilastras e foi reformado varias veces ao longo dos anos. A nave da igrexa é simple e carece case por completo de decoración, agás un viacrucis que recorre ambos muros e chega ata a capela maior.

Aos pés da nave está a tribuna que se hizo en la iglessia de Santa Martha año de mill setecientos y quarenta y siete (... $)^{36}$ (Doc. 2); nos Libros de Fábrica aparecen varias obras para o seu acondicionamento, como a levada a cabo entre 1909 e 1910 na cal se investiron cincocentas oitenta e cinco pesetas na madeira para a súa reforma ${ }^{37}$. As escaleiras que dan acceso a ela teñen o primeiro tramo construído en pedra e a continuación en madeira. A través da tribuna pódese acceder ao campanario mediante unha escaleira portátil. Tense referencia sobre unha escaleira no atrio que levaba á tribuna e a cal empregaron uns ladróns para roubar a arca onde se depositaban os caudais das confrarías no ano $1731^{38}$.

O teito desta parte da igrexa, tanto da nave como da tribuna, aparece cuberto a tres panos por un artesoado en forma de artesa invertida de madeira. A importancia desta peza radica no feito de que este tipo de armaduras son obras de arte que forman parte integrante do espazo arquitectónico, sendo non só un peche funcional destinado a cubrir un edificio, senón tamén un elemento plástico que establece unha determinada maneira de ver o interior. É un xeito de dignificar o espazo sagrado.

36 AHDO. Santa Marta de Moreiras. Libro de Fábrica 32.10 .17 (1711-1876) f. 45 v.

37 AHDO. Santa Marta de Moreiras. Libro de Fábrica 32.10 .18 (1853-1940) f. 65 r.

38 AHDO. Santa Marta de Moreiras. Libro de Fábrica 32.10 .17 (1711-1876) f. 99 r. 
Aínda que son moi poucos os exemplares conservados -sobre todo en Galizaeste tipo de armaduras debeu ser moi frecuente nos teitos das igrexas do rural galego. A explicación do seu uso está en que os muros, de escasa robustez, son máis aptos para soportar teitumes lixeiras que dan lugar a empuxes moi inferiores aos orixinados polas cubertas pétreas, ademais de razóns de tipo económico, por resultar a construción en madeira menos custosa e máis rápida de executar que as propias de cantería. Outras vantaxes son a fácil reposición das pezas danadas e as razóns estéticas, pola posibilidade de recibir labores diversos e policromía fronte ás austeras formas da arquitectura pétrea.

O material empregado, ao ser tan feble co paso do tempo, fixo que chegasen ata hoxe en día un número relativamente escaso do total. A propia caducidade da madeira (goteiras, tormentas, incendios) obrigou a renovar moitas das armaduras. As conservadas forman un conxunto importante e pouco coñecido, digno de atención polas súas especiais singularidades.

Desde un punto de vista tipolóxico, o artesoado de Moreiras responde á coñecida solución das armaduras de par e nudillo. A dous terzos da súa altura, entre cada dous pares ou alfardas, interponse un madeiro horizontal chamado nudillo. A sucesión destes crea unha superficie horizontal que oculta a fieira. Tal plano constitúe o almizate ou harneruelo, co que o aspecto triangular da teitume de parbilera se transforma nun perfil trapecial.

O resultado é unha cuberta cunha sección en forma de "A", mostrando ao espectador que se atopa no interior do edificio tres planos: dous laterais inclinados, os faldóns, e un central horizontal, o almizate ou harneruelo (Fig. 14).

Fig. 14. Armadura do teito da igrexa de Santa Marta.

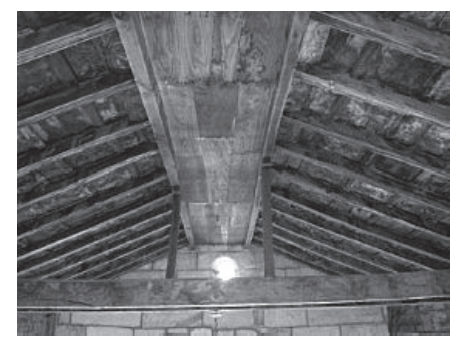

Ademais da armadura de Santa Marta de Moreiras, forman parte deste grupo de teitumes as que cobren as igrexas románicas de Santa Mariña de Augas Santas -a máis antiga- Santa Cruz de Arrabaldo, San Pedro de Trasalba, San Martín de Sabadelle, Santa María de Entrambosrríos, Santa Baia de Beiro e Santa María de Esposende ${ }^{39}$.

39 BARRIOCANAL LÓPEZ, Y. (1986): 295-316 
Todos os exemplares conservados en Ourense presentan unha decoración polícroma. A similitude de motivos e a técnica empregada evidencian que os labores polícromos foron feitos ao mesmo tempo e polos mesmos operarios que fabricaron as súas estruturas.

O teito de Santa Marta aparece decorado con varias figuras e aínda conserva a súa policromía, agás a rúa central que carece de ornamentación. Na decoración das tabicas da armadura dominan os motivos vexetais en estrita simetría, combinados con motivos híbridos de mascaróns metamorfoseados en vexetais. Tamén aparecen motivos figurados, con temas de natureza fantástica, tanto pegasos, de raíz clásica, como sereas portando peites e espellos, cuxa sedutora imaxe se asocia coa luxuria e a tentación (Figs. 15, 16, 17, 18).

Figs. 15-16-17-18. Detalle dos motivos decorativos do artesoado da igrexa de Santa Marta.
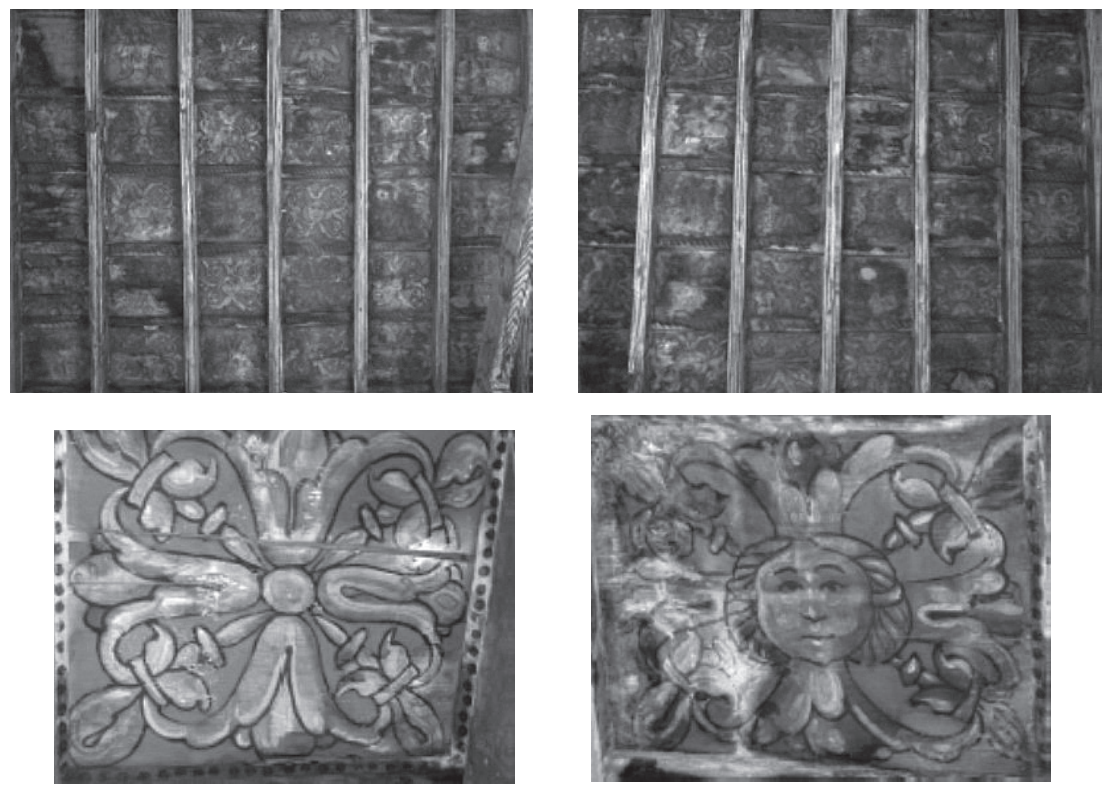

A decoración está pintada ao tempero, a man alzada e sen uso de plantillas. As liñas de contorno das imaxes son grosas e cuns trazos negros. A cor vermella predomina no conxunto ao aparecer de fondo en todas as composicións, alternando con cores grises. As imaxes son planas e carecen de volume.

As tirantas nas que se apoian os faldóns do artesoado están decoradas con motivos vexetais. A través dun eixo de simetría discorren as follas nervadas seguindo unha liña ondulante. Os trazos dos contornos tamén son negros e o interior está cuberto por cores terrosas. O fondo sobre o que se sitúan é vermello. As tirantas están rematadas por canzorros, tamén decorados por sinxelas liñas negras, con tallos que se bifurcan sobre un fondo sen pintar. 
Comparando o artesoado de Santa Marta co das igrexas de Sabadelle e Esposende, obsérvase que estas últimas teñen unha maior influencia mudéxar. En San Martín de Sabadelle ${ }^{40}$ a armadura de par e nudillo só conserva a lacería orixinal no seu tramo dianteiro. Aquí consérvase o almizate onde se insire o repertorio pictórico. Por outra banda, de Santa María de Esposende a información da que se pode botar man é a facilitada por Fernández Oxea ${ }^{41}$. Xa naquel tempo a igrexa só conservaba un fragmento de lacería no harneruelo da nave e outro na cabeceira. Os motivos pictóricos tamén están inseridos dentro do lazo.

Tanto estas dúas últimas igrexas como a de Santa Marta comparten unha decoración pictórica semellante e xa descrita, aínda que o artesoado de Santa Marta sexa moito máis simple e careza da influencia mudéxar que posúen as demais.

A parte do teito da tribuna que corresponde ao lado interior da fachada principal perdeu esta decoración, xa que tivo que ser reformado, como o da capela maior, debido ás humidades que penetraban polo campanario. Este problema xa ocorría desde 1740, cando se tivo que compoñer unha parte do teito desta zona ${ }^{42}$; en 1823 volvéronse realizar cambios na tribuna e no teito do campanario ${ }^{43}$; e xa no século $\mathrm{XX}$ se gastaron por cemento y cal para arreglar el campanario a fin de evitar la lluvia en las paredes y blanqueo de la Yglesia veinticuatro pesetas con cincuenta centimos $(. . .)^{44}$.

O chan da igrexa foi a parte do conxunto que menos modificacións sufriu, xa que ata o ano 1755 era de terra. Neste ano, o mestre de cantería Estevo García recibiu máis de trescentos cincuenta reais por lousar a igrexa con trinta sepulturas enteiras e dez de párvulos ${ }^{45}$. A obra máis recente que aparece recollida foi a realizada para embaldosar parte do pavimento entre os anos 1905-1906 $6^{46}$.

O conxunto parroquial está delimitado por un atrio do que xa se ten constancia a finais do século XVIII cando se realiza unha cancela para $\mathrm{el}^{47}$. Non se volve saber de ningunha reforma ata os anos noventa do século XIX cando tivo que reedificarse o seu muro ${ }^{48}$ e se lle fixeron unhas portas de ferro ${ }^{49}$, que foron colocadas en $1904^{50}$. As portas que hoxe en día conserva o conxunto son desta data, e poden ser as mesmas das que nos falan os Libros de Fábrica. A derradeira noticia sobre o

40 FERNÁNDEZ OXEA, X. R. (1943-1944): 250-257.

41 FERNÁNDEZ OXEA, X. R. (1941-1942): 165-175.

42 AHDO. Santa Marta de Moreiras. Libro de Fábrica 32.10 .17 (1711-1876) f. 39 r.

43 AHDO. Santa Marta de Moreiras. Libro de Fábrica 32.10.17 (1711-1876) f. 130 v.

44 AHDO. Santa Marta de Moreiras. Libro de Fábrica 32.10 .18 (1853-1940) f. 65 v.

45 AHDO. Santa Marta de Moreiras. Libro de Fábrica 32.10 .17 (1711-1876) f. 55 r.

46 AHDO. Santa Marta de Moreiras. Libro de Fábrica 32.10 .18 (1853-1940) f. 61 r.

47 AHDO. Santa Marta de Moreiras. Libro de Fábrica 32.10.17 (1711-1876) f. 39 r.

48 AHDO. Santa Marta de Moreiras. Libro de Fábrica 32.10 .18 (1853-1940) f. 48 r.

49 AHDO. Santa Marta de Moreiras. Libro de Fábrica 32.10 .18 (1853-1940) f. 48 v.

50 AHDO. Santa Marta de Moreiras. Libro de Fábrica 32.10 .18 (1853-1940) f. 59 r. 
atrio aparece no ano 1921, no que se gastaron por hacer la parte norte del muro del atrio de esta yglesia cuarenta y cinco pesetas ${ }^{51}$.

\section{Imaxinería, mobiliario litúrxico e ourivería: os libros de fábrica como fonte para un estudo artístico}

A capela maior da igrexa acolle un altar moi simple e apenas decorado, onde destacan as imaxes dunha Santa Marta na parte central superior e un Cristo na cruz á súa esquerda. Da talla da patroa tense noticia desde o ano 1568, cando nunha visita pastoral feita na igrexa se mandou aderezar o altar de Santa Lucía, hoxe perdido, e traer de volta á igrexa a imaxe de Santa Marta que estaba a pintar ${ }^{52}$. No reconto de bens e xoias de 1765 volve aparecer outra nova sobre unha Santa Marta (pola cal se gastaron en 1895 doscientos cuarenta reales por compostura, pintura y dorado (... $)^{53}$ ) que o abade mandara realizar e pintar en $1765^{54}$. A imaxe actual corresponde a unha talla do século XVII, de escasa calidade artística e moi minguada pola súa recente policromía (Fig. 19). A figura represéntase sobre unha peaña, vestida con túnica e cuberta cun manto. Segundo a habitual iconografía, aparece como unha versión feminina de San Xurxo, co balde ou caldeiro de auga bendita e levantando o hisopo en ademán de salpicar o dragón que xeralmente aparece vencido aos seus pés.

Nas pilastras que sustentan o arco sitúanse dúas imaxes mirando cara á nave: no lado esquerdo unha Virxe co neno e no dereito unha María Magdalena. A imaxe da Virxe é moi simple e non é orixinal. As roupas son de cores luminosas, co brazo esquerdo sustenta a figura do neno e está rematada por unha coroa. Non obstante, pese a que o recente repinte da talla borrou as súas calidades artísticas, a imaxe da Magdalena pode adscribirse á corrente manierista dos primeiros anos do século XVII que anuncia o barroco. Conforme a súa tradicional iconografía aparece representada cunha longa melena que cae sobre un luxoso vestido policromado en tons verdosos, azulados e ocres con remates e pequenos debuxos en pan de ouro. $\mathrm{Na}$ man esquerda sustenta un libro e un bote de perfume para a unción de Xesús e na dereita porta unha gran cruz, recubertos ambos atributos de pan de ouro (Fig. 20).

$\mathrm{Na}$ nave destacan dous altares dentro dunhas fornelas, un a cada lado, que agora acollen as imaxes da Inmaculada no lado esquerdo e de Xesucristo no lado de-

51 AHDO. Santa Marta de Moreiras. Libro de Fábrica 32.10 .18 (1853-1940) f. 74 v.

52 ACO. Libro de Visitas de los beneficios de este obispado de Orense, año de 1566 a 1569, en que era obispo el sr. D. Fernando Tricio de Arenzana, fol. 165 v. (Noticia facilitada pola profesora Yolanda Barriocanal López, Universidade de Vigo).

53 AHDO. Santa Marta de Moreiras. Libro de Fábrica 32.10 .18 (1853-1940) f. 50 v.

54 AHDO. Santa Marta de Moreiras. Libro de Fábrica 32.10 .17 (1711-1876) f. 69 r. v. 
reito do templo (ambas imaxes non son orixinais). Esta obra foi realizada en 1854, cando Francisco Cabaleiro recibiu catro reais por abrir nos altares da igrexa os ocos para entallar as aras ${ }^{55}$.

Fig. 19. Santa Marta.

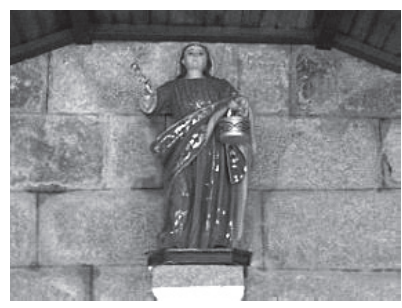

Fig. 20. María Magdalena.

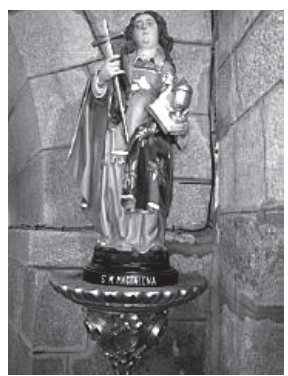

Ao lado de ambos altares sitúanse outras imaxes: na parte esquerda da nave aparece a Virxe do Carme sobre tres cabezas de anxos e protexida por un manto. Na man esquerda sostén un neno e na dereita porta o escapulario propio da súa advocación. Sobre a cabeza colocóuselle unha gran coroa rematada por unha cruz; e na parte dereita está a Virxe do Rosario, cunhas roupas policromadas en tons verdes e brancos e recuberta de pan de ouro. Aparece sostendo un neno no brazo esquerdo e coa man dereita recolle o rosario que a caracteriza. Ambas imaxes carecen de importancia ao ser bastante actuais e estar realizadas en pasta.

Nos Libros de Fábrica faise referencia a outras imaxes: unha Nosa Señora do Carme (non é a que se acaba de describir) que se mandou realizar e pintar e que aparece no reconto de bens e xoias de $1765^{56}$; e unha Purísima Concepción situada dentro dun pequeno armario e protexida por un vidro ${ }^{57}$.

Pero sen dúbida, a información máis interesante atopada sobre a escultura na igrexa de Santa Marta de Moreiras é a referente ao retablo que se mandou facer en 1758. O abade, Don Tomás Riol, pediu (...) para el maior aseo del culto divino se nezesita precisamente hazer un retablo en el altar maior de dicha yglesia por causa de no tener sino unas tablas y esas estar llenas de carcoma y muchas vezes caer en los corporales y algunas dentro del caliz por cuia causa no se puede decir misa (...) $)^{58}$ (Doc. 3).

A licenza para a obra foille concedida polo bispo e así, axustaron o retablo a Ángel Fernández en 1759: Costo el retablo q se ajusto a Angel Fdz vezino de Framontaos, q le ajustamos Don Matías Rz, Benito Tesoro, Domingo Blanco, Pedro Alvarez y otros mas todos vezinos de esta freguesia en mily dos cientos reales fuera el conducirlo y sentarlo. Costo la patrona ciento

55 AHDO. Santa Marta de Moreiras. Libro de Fábrica 32.10 .18 (1853-1940) f. 7 r. 7 v.

56 AHDO. Santa Marta de Moreiras. Libro de Fábrica 32.10 .17 (1711-1876) f. 69 r. v.

57 AHDO. Santa Marta de Moreiras. Libro de Fábrica 32.10 .18 (1853-1940) f. 47 r.

58 AHDO. Santa Marta de Moreiras. Libro de Fábrica 32.10 .17 (1711-1876) f. 56 v. 57 r. 
y ochenta y ocho $r$. Costo el asentarlo quatro dias sesenta y dos $r$. Costo la cerradura y una vara de cinta para la llave del sagrario catorce reales. $Y$ asi tuvo de todo coste el retablo y patrona con los mas gastos arriva mil quatrocientos sesenta y cuatro reales; $y$ con los doscientos y cinquenta reales $q$ me gaste en los ornatos hacen mil setecientos y catorce reales, los q todos se sacaron de el arca del deposito oy dia 20 de julio a año de mil setecientos y cinquen y nuebe siendo testigos el depositario Benito Tesoro q entrego, Domingo Blanco, Francisco Fz, Pedro Alvarezy otros.

Nota. Q aunq saque licencia del Sr Obispo Dn Fray Agustín de Eura para q las cofradias del Rosario y la Magdalena surtiesen con la mitad como consta de la licencia al folio 56 vuelta; no quisieron los feligreses y asi todo lo costeo la fabrica gra a Dios $q$ abora ya se puede decir misa. Dios me de salud si me combiene y medios y a la fabrica para pintarlo. ${ }^{59}$

As tarefas de pintura foron encargadas a un mestre pintor do cal se conserva un documento de 1770 (Doc. 4) no que se reflicte o seu traballo neste retablo ${ }^{60}$, ademais doutros encargos como foron a patroa, cruz, marco e caixa de ánimas, o que unido ao retablo sumaron 1804 reais $^{61}$.

No último cuarto do século XIX aparece outra anotación referida a un retablo: yd veinte al carpintero incluido importe de la madera por hacer un retablo en el altar ma$y o r^{62}$. A causa disto, pode pensarse que as malas condicións de humidade nas que vivía a capela maior puideron ser o detonante para a desaparición do primixenio retablo, como así ocorreu con parte do artesoado que cubría esta zona.

Fig. 21. Cruceiro.

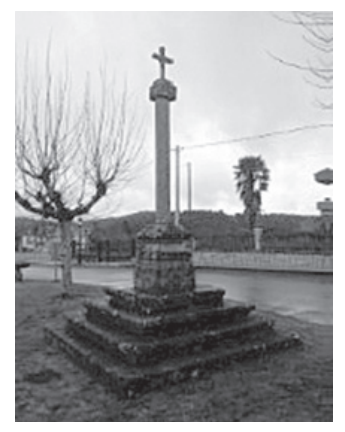

Xa fóra da igrexa e levantado no campo aínda hoxe en día se ergue un cruceiro colocado sobre catro chanzos. A columna que o conforma apóiase sobre unha peaña con molduras e remata na parte superior cun anaco de entaboamento sobre o

59 AHDO. Santa Marta de Moreiras. Libro de Fábrica 32.10 .17 (1711-1876) f. 98 v.

60 AHDO. Santa Marta de Moreiras. Libro de Fábrica 32.10.17 (1711-1876) f. solto entre 72 v. $73 \mathrm{r}$.

61 AHDO. Santa Marta de Moreiras. Libro de Fábrica 32.10 .17 (1711-1876) f. 73 r.

62 AHDO. Santa Marta de Moreiras. Libro de Fábrica 32.10 .18 (1853-1940) f. 33 v. 
que se sitúa unha cruz (Fig. 21). Carece de interese artístico e a única anotación que apareceu sobre el é a seguinte: cuatrocientos $r$ comedidos para conclusion y pinturas del crucero levantado en el campo a expensas del que suscribe y de algunos devotos ${ }^{63}$.

Nas igrexas era frecuente a presenza de caixóns para gardar as roupas litúrxicas, confesionarios, escanos para enterrar os membros das moitas confrarías e diferentes elementos para a configuración do Monumento na Semana Santa.

Lamentablemente, a perda deste mobiliario foi grande debido ao seu continuado uso e ao carácter perecedoiro da madeira, sendo moi poucas as pezas que chegaron ata nós. Aínda que o seu valor artístico sexa máis propio do campo da ebanistería que do da escultura, son pezas executadas polos entalladores da época que merecen ser documentadas para coñecer o mobiliario destas parroquias.

Na igrexa de Santa Marta de Moreiras o mobiliario foi escaso, como corresponde a unha igrexa de limitada importancia. Non obstante, os Libros de Fábrica achegan algunhas noticias acerca da súa existencia. Así, tense constancia da cuenta y razon por menudo de todo el coste q tuvieron los cajones de la sacristia de Santa Martha con sus dos tablas colaterales; los quales se bizieron año de mill setecientos y treinta y ocho ${ }^{64}$. Estes caixóns consérvanse na sancristía da igrexa e están en moi bo estado, sendo unha mostra do gusto decorativo da época.

Estruturalmente, a caixonería componse dun moble de dobres caixóns amplos e profundos para gardar as roupas litúrxicas. Ao carácter de utilidade hai que engadir a busca do deseño e a beleza nos seus motivos decorativos, a base dunha talla a bisel con temas vexetais percorrendo a súa fronte (Fig. 22).

Fig. 22. Caixonería. Sancristía da igrexa de Santa Marta.

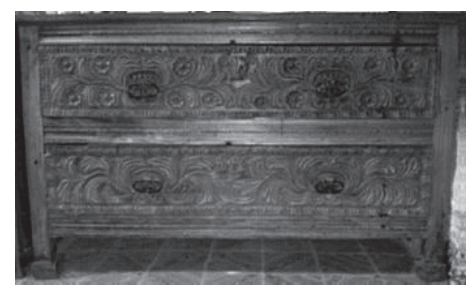

Outros obxectos que carecen de moita importancia son catro arcas e dous bancos de respaldo ${ }^{65}$; un atril novo que se mandou facer ao tallista Don Manuel Varela de Ourense para o altar maior en $1857^{66}$; e un confesionario pechado ${ }^{67}$

63 AHDO. Santa Marta de Moreiras. Libro de Fábrica 32.10 .18 (1853-1940) f. 33 v.

64 AHDO. Santa Marta de Moreiras. Libro de Fábrica 32.10.17. (1711-1876) f. 36 v.

65 AHDO. Santa Marta de Moreiras. Libro de Fábrica 32.10.17. (1711-1876) f. 69 r. v.

66 AHDO. Santa Marta de Moreiras. Libro de Fábrica 32.10.18. (1853-1940) f. 13 r.

67 AHDO. Santa Marta de Moreiras. Libro de Fábrica 32.10.17. (1711-1876) f. 6 v. 
no que se gastaron catro reais para facer de celosía a porta ${ }^{68}$. Todos estes mobles hoxe en día están desaparecidos ou foron cambiados por outros co paso do tempo.

A única peza deste tempo que aínda hoxe se conserva é un confesionario. Foi feito para a igrexa de Santa Marta, hoxe en día atópase na capela dos Gozos (Fig. 23): por un bonito y comodo confesonario pinotea que dono a esta Yglesia. Consigno esto por temer a morir y que lo hagan figurar en cuentas sucesivas. Y para que así conste firmo y sello las presentes a primero de enero de mil novecientos diecisiete. Manuel Nieves ${ }^{69}$.

Fig. 23. Confesionario.

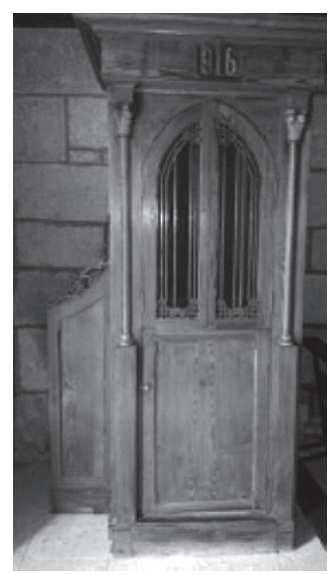

No relativo á configuración do Monumento para a Semana Santa só aparece unha referencia na que se gastaron trinta reais para a escaleira do monumento e que foi axustada a Gabriel Ribau ${ }^{70}$.

Coma todas as igrexas pequenas e dunha escasa importancia, os obxectos de ourivería que se atopan na igrexa de Santa Marta de Moreiras son moi simples. Nos Libros de Fábrica hai numerosas referencias a eles, pese a que na actualidade non se conserva ningunha das pezas.

Durante o século XVIII, máis concretamente desde 1711, ata a primeira metade do século XIX son poucas as referencias a estes obxectos. Así, no citado ano compuxéronse unhas aceiteiras por valor dun real ${ }^{71}$ e no 1732 volvéronse facer outras novas de estaño co seu pratiño por un importe de 20 reais $^{72}$. No ano 1727

68 AHDO. Santa Marta de Moreiras. Libro de Fábrica 32.10.17. (1711-1876) f. 39 r.

69 AHDO. Santa Marta de Moreiras. Libro de Fábrica 32.10.18. (1853-1940) f. 70 v.

70 AHDO. Santa Marta de Moreiras. Libro de Fábrica 32.10.17. (1711-1876) f. 101 r.

71 AHDO. Santa Marta de Moreiras. Libro de Fábrica 32.10.17. (1711-1876) f. 4 r.

72 AHDO. Santa Marta de Moreiras. Libro de Fábrica 32.10.17. (1711-1876) f. 27 v. 
compúxose un cáliz ${ }^{73}$ que tivo que ser reedificado un tempo despois polo prateiro de Ourense Francisco Antonio de Mira ${ }^{74}$ e custou 11 reais e 18 marabedís ${ }^{75}$.

No reconto de bens e xoias da igrexa correspondente ao ano 1765 figuran as seguintes pezas: unha cruz de prata, dous cálices, dúas patenas sobredouradas, un relicario de peito que servía ás dúas parroquias, un copón dourado por dentro, dúas aceiteiras co seu pratiño de estaño, cinco candeeiros de "aljofar", unha cruz de latón vella, un incensario de latón vello e unhas crismeiras que tamén servían ás dúas parroquias ${ }^{76}$.

24 reais custou o Santo Cristo de bronce que se colocou enriba da custodia no altar maior en $1779^{77}$; uns anos despois, en 1781, aparece a seguinte anotación: que avra unos 18 años q robaron esta yglesia el dinero q estava en el arca de el pasillo para bacer una cruz de plata: y este año a veynte y seis de abril de mil setecientos y ochenta y uno (gracias a Dios) sustituyeron 86 rs los q se distribuyeron en lo siguiente; compraronse dos lamparas de oja de lata (...) mas catorze reale de componer la cruz de plata (...) $)^{78}$. Aquí recóllese un dos numerosos roubos aos que estivo sometida a igrexa ao longo do tempo, razón pola cal se supón os obxectos cos que esta contaba non eran de moita calidade e os que si tiñan algo de valor non chegaron ata os nosos días.

No 1783 realizouse un incensario coa súa naveta e culler todo de metal, cuxo prezo ascendeu a 76 reais $^{79}$; xa comezado o novo século, en 1813 recóllese unha noticia significativa, cando (...) se mando hacer un copon para la yglesia de Santa Marta por haveren robado los franceses el $q$ habia en dicha yglesia y se bizo con consentimiento de todos los feligreses a quenta de los alcances de la fabrica (... $)^{80}$.

Outro reconto de bens e xoias feito no ano 1835 informa sobre as pezas de ourivería do templo: unha cruz de prata novamente composta con perfección, dous cálices de prata (un deles sen culler pero coas súas patenas), un copón de prata moi bo, un relicario de prata que servía ás dúas igrexas, unhas crismeiras completas, unha cruz boa de metal, catro candeeiros bos, un crucifixo, dúas campaíñas, un incensario en bo estado e unha naveta con culler moi bos ${ }^{81}$.

As pezas de ourivería increméntanse desde mediados do século XIX. Deste xeito, en 1853 anótanse 5 reais e 6 marabedís de custo dunha culler de prata para un dos cálices da igrexa, que non a tiña, e da cinta para colgala do purificador; 7

73 AHDO. Santa Marta de Moreiras. Libro de Fábrica 32.10 .17 (1711-1876) f. 18 r.

74 AHDO. Santa Marta de Moreiras. Libro de Fábrica 32.10.17 (1711-1876) f. 24 r.

75 AHDO. Santa Marta de Moreiras. Libro de Fábrica 32.10.17 (1711-1876) f. $20 \mathrm{v}$.

76 AHDO. Santa Marta de Moreiras. Libro de Fábrica 32.10. 17. (1711-1876) f. 69 r. v.

77 AHDO. Santa Marta de Moreiras. Libro de Fábrica 32.10.17. (1711-1876) f. 84 r.

78 AHDO. Santa Marta de Moreiras. Libro de Fábrica 32.10.17. (1711-1876) f. 84 r.

79 AHDO. Santa Marta de Moreiras. Libro de Fábrica 32.10.17. (1711-1876) f. 88 v. 89 r

80 AHDO. Santa Marta de Moreiras. Libro de Fábrica 32.10 .17 (1711-1876) f. 120 v.

81 AHDO. Santa Marta de Moreiras. Libro de Fábrica 32.10.17 (1711-1876) f. 146 r. 
reais que custou un pratiño de folla de lata para as aceiteiras e a composición das mesmas $^{82}$.

No ano seguinte anótanse 176 reais que importou a feitura dun relicario ou caixiña para levar o sagrado viático e a crismeira para os santos óleos dos enfermos, segundo constaba no recibo do prateiro de Ourense José Menéndez ${ }^{83}$. En 1857 realizáronse dous novos candeeiros para a igrexa nos que se investiron 24 reais $^{84}$.

Os anos sesenta foron os que viron chegar á igrexa un maior número de pezas. No 1861 mandáronse facer dúas aceiteiras co seu pratiño por 12 reais e compoñer unha cruz manual e unha culler para o cáliz por seis reais ${ }^{85}$. Dous anos despois gastáronse 24 reais na composición da cruz procesional e trouxéronse outros dous novos candeeiros de bronce por 27 reais $^{86}$; ao ano seguinte a suma por un incensario, unha naveta e unha campaíña "sobreprateada" ascendeu a 216 reais ${ }^{87}$.

En 1872 gastáronse 20 reais nun copón de cristal para a custodia ${ }^{88}$ e no ano 1883 chegaron á igrexa seis novos candeeiros, unha cruz de metal branco, unha patena cuberta de prata e un cáliz dourado a lume ${ }^{89}$.

Xa no século $\mathrm{XX}$ as pezas de ourivería son menos que nas épocas anteriores, mais púidose atopar información sobre elas. Entre 1901-1902 fixéronse unhas aceiteiras de metal dourado co seu pratiño e campaíña ${ }^{90}$; no 1905-1906 custaron 60 pesetas un copón, unha caixa para as hostias e un vaso para purificar todo de prata meneses ${ }^{91}$; en 1929 mandouse facer un incensario de metal por 40 pesetas $^{92}$; e como derradeiro dato aparecen unhas aceiteiras e dous candelabros de metal mandados facer en $1937^{93}$.

Hoxe en día a parroquia conta, segundo o inventario de fondos parroquiais ${ }^{94}$, cunha cruz procesional do século XVIII de prata (Fig. 24); tres cálices e dous copóns tamén de prata do século XIX; e un portaviático, unha coroa e unha crismeira de prata todo do século XX.

82 AHDO. Santa Marta de Moreiras. Libro de Fábrica 32.10.18. (1853-1940) f. 2 v.

83 AHDO. Santa Marta de Moreiras. Libro de Fábrica 32.10.18. (1853-1940) f. 5 r.

84 AHDO. Santa Marta de Moreiras. Libro de Fábrica 32.10.18. (1853-1940) f. 13 r.

85 AHDO. Santa Marta de Moreiras. Libro de Fábrica 32.10.18. (1853-1940) f. 20 r.

86 AHDO. Santa Marta de Moreiras. Libro de Fábrica 32.10.18. (1853-1940) f. 23 v.

87 AHDO. Santa Marta de Moreiras. Libro de Fábrica 32.10.18. (1853-1940) f. 24 v.

88 AHDO. Santa Marta de Moreiras. Libro de Fábrica 32.10.18. (1853-1940) f. 31 v.

89 AHDO. Santa Marta de Moreiras. Libro de Fábrica 32.10.18. (1853-1940) f. 42 r.

90 AHDO. Santa Marta de Moreiras. Libro de Fábrica 32.10.18. (1853-1940) f. 56 r.

91 AHDO. Santa Marta de Moreiras. Libro de Fábrica 32.10.18. (1853-1940) f. 61 r.

92 AHDO. Santa Marta de Moreiras. Libro de Fábrica 32.10.18. (1853-1940) f. 78 r.

93 AHDO. Santa Marta de Moreiras. Libro de Fábrica 32.10.18. (1853-1940) f. 83 v. (sen paxinar).

94 BANDE RODRÍGUEZ, E. e TAÍN CARRIL, C. (2000). 
Fig. 24. Cruz procesional de prata (anverso e reverso).
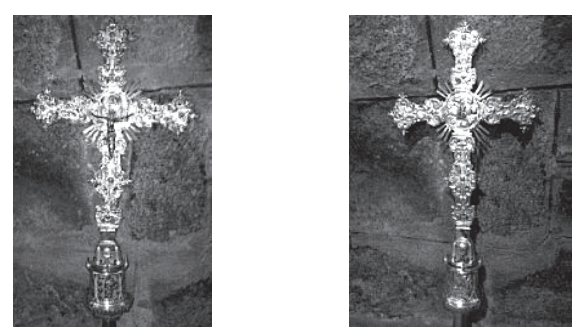

Con respecto á cruz, é de estilo rococó, a excepción da macolla que pertence ao século XVII e está decorada na súa fronte co tema da Inmaculada Concepción. A cruz leva as contornas dos brazos perfiladas con elementos florais e rocallas como clásicos motivos decorativos do repertorio rococó. No anverso aparece Cristo crucificado mentres que no disco do reverso se representa a Santa Marta axeonllada entre nubes con elementos propios da súa iconografía: o hisopo e o caldeiro.

\section{Capelas parroquiais}

\section{- Capela dos Gozos}

A capela dos Gozos foi erguida a mediados do século XVII nos terreos que lle foron concedidos a Pedro Rodríguez Pantaleón: en junto a los molinos que dicen de Pedrayo jurisdicción de Aguiar fra. De Santa Marta de Moreiras a quince días del mes de marzo del año de mil y seiscientos y treinta y cuatro años ante mi escribano y testigos pareció presente Pedro Dobale, vecino del dho lugar de Pedrayo y dijo que por cuanto Pedro Rodríguez Pantaleón, natural del lugar do Gurñal, vecino de la villa de Madrid religioso de la tercera orden de Santo Domingo quiere trasladar la hermita del Señor San Pedro que está caída en el lugar de Pedrayo, por tanto, para que el dh. Pedro Pantaleón, la pueda redificar el dh. Pedro Dobal que presente estaba que para que la pueda hacer y redificar dixo que en la vía y forma que mejor haya lugar de derecho hacia e hizo gracia y donación pura mera perfecta irrevocable que el derecho llama entre vivos de dos cuartos de sembradura de heredad en la cabexera de la Cortiña que está a lo largo del camino que viene de la ciudad de Orense, y va para el Castro de Caldelas, $y$ otras partes para que en ella pueda edificar y edifique la bermita que tiene en devoción de redificar y trasladar dende el lugar de Pedrayo al dh. Sitio y lugar que le da y dona por cuanto en lo que a el dh. Pedro Rodríguez Pantaleón, es obra meritoria y servicio de Dios y el señor San Pedro y el dh. Pedro Dobal por su devoción y servicio del señor San Pedro se lo da según que el dh. Sitio que ansi le da para la dh. obra (... $)^{95}$.

95 FERNÁNDEZ OXEA, X. R. (1982): 81. 
Existía o documento fundacional desta capela, pero foi extraviado cando o Maxistral da Catedral de Ourense llo pediu ao párroco de Santa Marta de Moreiras $^{96}$ a comezos do século XX.

A súa planta é rectangular e está dividida en tres tramos por dous arcos faixóns. Na cabeceira sitúase a sancristía, que se comunica coa nave a través de dúas portas colocadas a cada lado do altar maior. A importancia dada á capela maior tradúcese no exterior nunha maior altura e alongamento da planta (Fig. 25).

As cubertas do tellado son diferentes en cada parte: a nave está cuberta a dúas augas, a capela maior a catro e a sancristía a tres. Os sillares son regulares e agás a fachada principal, o resto do conxunto carece de decoración.

$\mathrm{Na}$ fachada ábrese unha porta alintelada enmarcada por unha sinxela moldura crebada na parte superior. Enriba colócase un balcón que acolle un altar flanqueado por unha fiestra no lado esquerdo e unha porta no lado dereito, a través da que se accede á tribuna.

O altar está composto por unha fornela rematada por un arco de medio punto decorado cunha concha de vieira no seu interior e os bordes cunha moldura ondulada. Apóiase este en dúas pilastras decoradas e rematadas por capiteis de estilo corintio. Outras dúas pilastras estriadas acollen no seu interior a fornela, rematando estas en dous capiteis dóricos que sosteñen un lintel a modo de entaboamento. Enriba sitúase un tímpano curvo cunha moldura e unhas pequenas pirámides a cada lado como prolongación das pilastras. Na clave unha cruz remata o conxunto.

Dúas pilastras lisas delimitan a composición e resaltan da fachada polas bases e os capiteis con molduras, sobre os cales se apoia un entaboamento que á súa vez sustenta uns afiados pináculos. A moldura que recobre o entaboamento vaise curvando cara á base da espadana, onde remata formando unha voluta a cada lado desta, ao mesmo tempo que sustenta unhas escaleiras que van cara a espadana.

Fig. 25. Planimetría da Capela dos Gozos.

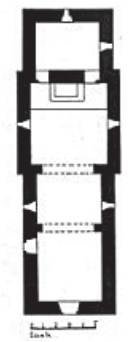

Fonte: FERNÁNDEZ OXEA, X. R. (1982): 117.
Fig. 26. Fachada e parte sur da Capela dos Gozos.

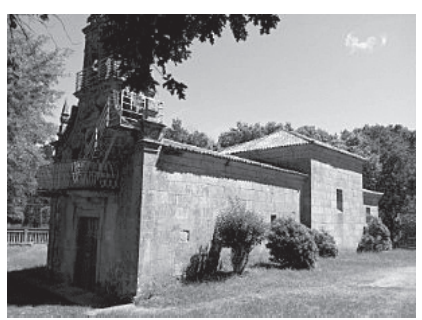

96 FERNÁNDEZ OXEA, X. R. (1982): 58. 
A espadana ten dous corpos. O primeiro está formado por tres pilastras con bases estriadas e decoración de cartelas, sobre as que se apoian dous arcos de medio punto que acollen as campás. As pilastras laterais voan sobre o entaboamento superior e rematan en dúas pirámides, entre as que se atopa o segundo corpo da espadana. Está composto por dúas pilastras estriadas que acollen no seu interior un oco baleiro. Sobre este disponse un gran baquetón que sustenta en cada extremo sendas pirámides. Remata o conxunto cunha pirámide truncada sobre o baquetón e sobre esta unha cruz cun viraventos (Fig. 26).

No interior, o templo ten unha decoración bastante sobria. A capela maior, cun teito plano de xeso apoiado sobre pendentes, mostra no seu frontal un pequeno retablo situado sobre unha peaña e entre dúas portas que dan acceso á sancristía. Este está formado por tres espazos nos que se aloxa a Virxe co neno no centro e un santo a cada lado. Na parte inferior da Virxe está aloxado o sagrario. Un pequeno altar ocupa o espazo central e no lateral esquerdo está o carriño coa virxe que serve para sacala en procesión cando é o tempo da romaría (Fig. 27).

Fig. 27. Capela maior da Capela dos Gozos.

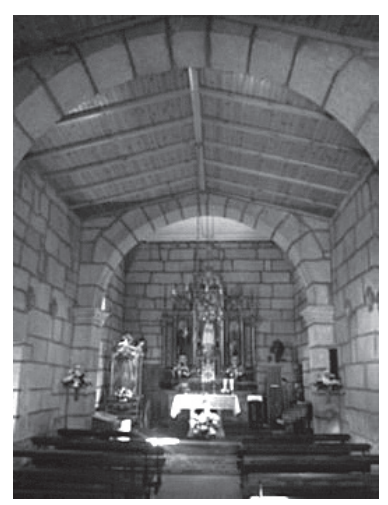

Unha grada de cantería e un arco faixón de medio punto separan o presbiterio do resto da nave. Esta aparece dividida en dúas zonas por outro arco faixón. A cuberta a dúas augas é de madeira e carece de decoración, o mesmo que ocorre na nave, onde os únicos ornatos son pequenas imaxes con cruces de madeira que representan o viacrucis e percorren ambos laterais e pasan pola cabeceira.

Aos pés da nave levántase a tribuna, cunhas escaleiras no lado dereito que dan acceso a ela. No lado esquerdo colocouse un confesionario, xa citado anteriormente, que pertence á igrexa de Santa Marta, pero que por motivos de espazo se tivo que trasladar aquí.

O 4 de agosto de 1658, o mecenas desta capela e veciño de Madrid, Pedro Rodríguez Pantaleón, reuniuse co veciño de Ourense e mestre de cantería Domingos 
García para que alargase a capela maior da ermida dos Gozos, ademais de levantala en altura unha vara castelá, pagándolle por este traballo oitenta ducados de a once reais cada un. En outubro rematou a obra e Don Pedro pagoulle o estipulado ${ }^{97}$.

Un dos elementos máis destacados desta capela foi o seu retablo, do que se conserva o protocolo notarial ${ }^{98}$ da escritura sobre o seu axuste ${ }^{99}$ (Doc. 5) en 1696 a Benito Rodríguez Muxica e a traza deste ${ }^{100}$. A conservación desta traza é un feito a destacar, dada a xeral perda destes documentos que normalmente quedan en mans do comitente ou do mestre encargado da súa execución

A traza do retablo só mostra o lateral esquerdo deste. Componse dun zócalo ou baseamento sobre o que se alza unha gran fornela formada por un arco de medio punto sustentado sobre unha columna a cada lado con capitel. A columna esquerda mostra os inicios duns motivos ornamentais, mais non se completa a decoración. A fornela está flanqueada por unha columna salomónica a cada lado: na parte esquerda o fuste da columna divídese en tres tramos con decoración de estrías en diferente dirección cada unha e aparece rematada por un gran capitel corintio con follas de acanto; na parte dereita trátase dunha columna salomónica dun só corpo decorada con liñas serpeantes das que colgan acios de uvas e rematada tamén por un capitel corintio. Rematando esta parte sitúase un gran entaboamento moldurado sobre o que se ergue no extremo esquerdo un pináculo e cara a zona dereita obsérvase o lateral da moldura que levaría o retablo na rúa central, formado por motivos ornamentais circulares e rematada por outro pináculo (Fig. 28).

Fig. 28. Traza do retablo da Capela dos Gozos. AHDO. Protocolo de Antonio Pérez de Araujo. 1690-1696. Caixa 600. Leg. 600.02., p. 151 r.

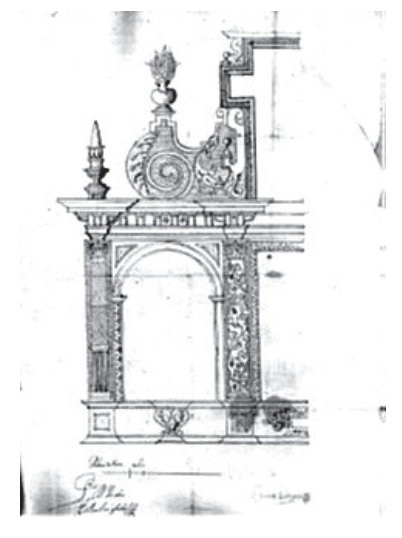

97 AHPOU. Protocolos Notariais. Caixa 3491 en HERVELLA VÁZQUEZ, J. (1996): 12.

98 AHDO. Protocolo de Antonio Pérez de Araujo. 1690-1696. Caixa 600. Leg. 600.02, pp. 149 r. v.- $150 \mathrm{r}$.

99 FERNÁNDEZ OXEA, X. R. (1982): 91-93.

100 AHDO. Protocolo de Antonio Pérez de Araujo. 1690-1696. Caixa 600. Leg. 600.02, p. 148 r. 
$\mathrm{Na}$ escritura do contrato o entallador comprométese a facer un retablo con catro caixas, unha para o Santo Cristo, outra para a Nosa Señora e dúas aos lados para San Pedro e Santo Domingo, cos labores de cartón froiteiro e realces que manifesta a planta, ademais de catro columnas salomónicas e non triangulares. Os respaldos das caixas teñen que ser de madeira boa de nogueira e de castaño ${ }^{101}$.

Benito Rodríguez Muxica ou Moxica foi un entallador barroco do cal apenas se teñen noticias, sendo as primeiras as recollidas por Pérez Constanti ${ }^{102}$. Pertenceu, coma moitos outros, a talleres inscritos na órbita de escultores e entalladores de máis renome, polo que do seu paso por Ourense son contadas as obras das que se ten noticia. En territorio ourensán estivo entre os anos $1690-1698^{103}$, realizando obras nunha xeografía distante da capital.

Sábese que realizou os retablos da Nosa Señora de Reza, da capela de San Cosme e San Damián de Ourense, da Nosa Señora do Campo de Mourisco e o da capela que se está a tratar, a Nosa Señora dos Gozos; mais o seu nome vai ligado á súa principal realización: o retablo para a capela de San Xoán da sé auriense ${ }^{104}$.

\section{- Capela de Santa Catalina. Cimadevila}

A capela de Santa Catalina está situada no lugar de Cimadevila. Segundo Fernández Oxea ${ }^{105}$, a súa fundación é anterior á das igrexas parroquiais de Santa Marta e San Martiño, xa que a tradición oral asegura que a súa primitiva construción foi sobre castro do mesmo nome. Como a diario aparecían as portas abertas decidiuse trasladala ao lugar no que hoxe se sitúa.

É una capela de dimensións reducidas e moi atractiva á vista. A súa planta é rectangular e está cuberta por un tellado a tres augas. Os muros son de sillería regular e non teñen decoración algunha. A fachada amosa unha porta alintelada con dúas fiestras rectangulares a cada lado. No piñón sitúase unha pequena espadana cun oco para una campana con su cepo y badal ${ }^{106}$ e remátase o conxunto cunha sinxela cruz (Fig. 29).

O interior continúa a liña sobria que se intúe desde fóra. O altar está pegado ao muro, como é común nestas capelas tan pequenas, e sobre el hai unha peaña na cal se apoia a imaxe de Santa Catalina. Ao lado dereito dela sitúase un Cristo crucificado e ao esquerdo San Benito co neno.

101 FERNÁNDEZ OXEA, X. R. (1982): 91-92.

102 PÉREZ CONSTANTI, P. (1988): 482-483.

103 GONZÁLEZ GARCÍA, M. A. (1992-1993): 95-122.

104 GONZÁLEZ GARCÍA, M. A. (1992-1993): 95-122.

105 FERNÁNDEZ OXEA, X. R. (1982: )56.

106 AHDO. Santa Marta de Moreiras. Libro de Fábrica 32.10 .17 (1711-1876) f. 148 r. 
Fig. 29. Capela de Santa Catalina.

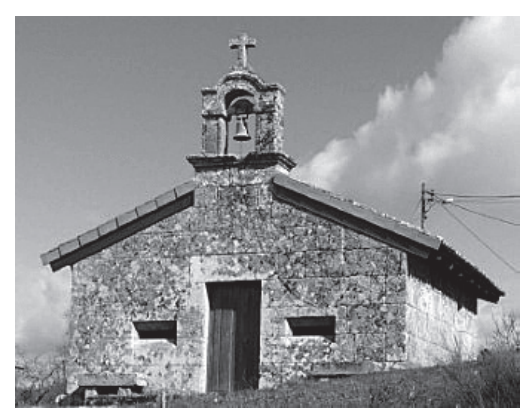

No muro norte aparece outra imaxe e no sur un van dálle iluminación ao conxunto e outro toma as veces de sagrario. A capela está cuberta cun teito de madeira moi reformado actualmente.

Apenas hai información sobre a súa construción, que se supón foi arredor do século XVII, e nos Libros de Fábrica só aparecen algúns datos sobre o que conservaba en 1835, como una imagen de Santa Catalina; un caliz con su patena y sin cuchara $(. . .)^{107}$.

\section{- Capela da Nosa Señora do Socorro. Pedraio}

A capela do Socorro está no lugar de Pedraio. A planta é cadrada e ten un pórtico pechado na parte dianteira. Está cuberta a nave por un tellado a dúas augas e o pórtico por un a tres augas. Os muros son de sillería regular e sen decoración (Fig. 30).

Fig. 30. Capela do Socorro.

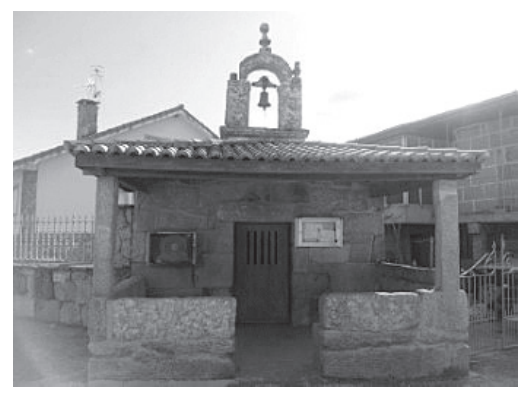

A fachada principal ten unha pequena porta alintelada de madeira que permite ver o interior a través duns ocos. A parte superior está decorada por unha pequena espadana cun só oco para albergar a campá. O interior apenas ten interese. Enriba

107 AHDO. Santa Marta de Moreiras. Libro de Fábrica 32.10.17 (1711-1876) f. 148 r. 
do altar e pegado ao muro álzase un pequeno retablo todo carcomido que acolle a imaxe da Virxe. A cuberta interior do teito é de madeira.

Suponse que esta capela é a reconstrución da anterior dedicada a San Pedro e que no século XVII estaba arruinada ${ }^{108}$.

\section{Conclusións}

Como se viu ao longo do traballo, a igrexa de Santa Marta de Moreiras é un expoñente máis do románico rural galego de finais do século XIII e comezos do XIV. Pese a todas as modificacións que sufriu ao longo dos anos, o conxunto non variou moito e conserva os seus trazos definitorios románicos. A influencia da Catedral de Ourense nestes templos da súa contorna foi moi notable, xa non polo influxo nos motivos ornamentais, senón polos mestres que atraía e que posteriormente se desprazaban a estes templos menores a plasmar os seus programas iconográficos.

$\mathrm{Xa}$ se puido apreciar anteriormente que estes mestres realizaban unha gran cantidade de obras, mais a súa modestia impide que figuren nalgún repertorio de artistas, o que dificulta enormemente o traballo investigador. Sumado a isto, á hora do traballo de arquivo atopouse un problema: o libro que recollía todos os recibos das obras realizadas na igrexa entre 1853-1940 estaba extraviado, polo que non sabemos que obras en concreto se realizaron na igrexa.

Outro aspecto que se comprobou foi a progresiva desaparición do patrimonio. Co avanzar dos anos cada vez había menos mobiliario na igrexa, xa sexa por envellecemento, roubo ou simple desaparición. De feito, das moitas pezas de ourivería que o templo tivo hoxe en día só permanecen nel un número insignificante. $\mathrm{O}$ mobiliario litúrxico foise abandonando no seu uso, as pezas foron carcomidas e tiveron que tirarse sen preocuparse por reparalas. Isto ocorreu cos retablos da igrexa parroquial e da capela dos Gozos, que aínda que non eran grandes obras, tiñan un grande interese histórico e artístico. En Santa Marta de Moreiras, ademais de desfacerse do retablo tiveron que substituír o teito de toda a capela maior e parte do da tribuna por falta de coidado contra as humidades, perdendo así unha parte importante do artesoado de influencia mudéxar que recubría a igrexa.

Estas igrexas rurais son descoñecidas para a maior parte da poboación, aínda que nos últimos tempos está en auxe o turismo artístico e relixioso. A non ser que se trate de grandes templos apenas se dan a coñecer estas construcións, que na maior parte das ocasións agochan no seu interior verdadeiras xoias como a que

108 FERNÁNDEZ OXEA, X. R. (1982): 123. 
estamos a tratar, onde o achado do artesoado foi moi sorprendente. Animar a que se sigan estudando e catalogando estas obras é un dos obxectivos deste traballo, sobre todo porque en Galiza abondan as construcións relixiosas e as variedades dentro dun mesmo estilo son moi numerosas, o que dá pé a estudos heteroxéneos e con novas perspectivas dentro do plano artístico. 


\section{Bibliografía E FONTES}

\section{- Bibliografía}

Bande Rodríguez, E. e Taín Carril, C. (2000): Inventario de fondos parroquiales, Ourense, Deputación Provincial.

Barriocanal López, Y. (1986): "Restos mudéjares en la provincia de Orense: armaduras de madera”, Boletín Avriense, n⿳ XVI, Ourense, pp. 295-316.

Barriocanal López, Y. (1994): "El fiel contraste de oro y plata de la ciudad de Orense en el siglo XVIII”, Boletín Avriense, $\mathrm{n}^{\circ}$ XXIV, Ourense, pp. 337-342.

Cid, C. (1917): "Una visita pastoral de la diócesis auriense en 1487. (Continuación)", Boletín de la Comisión Provincial de Monumentos Históricos y Artísticos de Orense, t. V, $\mathrm{n}^{\mathrm{o}}$ 116, Ourense, pp. 352-358

Fernández Oxea, X. R. (1941-1942): "Santa Marina de Esposende: iglesias medioevales gallegas”, Boletín del Seminario de Estudios de Arte y Arqueología, t. VIII, Valladolid, Universidad de Valladolid, pp. 165-175.

Fernández Oxea, X. R. (1943-1944): "San Martín de Sabadelle”, Boletín de la Comisión de Monumentos de Orense, t. XIV, Ourense, pp. 250-257.

Fernández Oxea, X. R. (1982): Santa Martad e Moreiras. Monografía dunha parroquia ourensán (1925-1935), Cuadernos do Seminario de Sargadelos, 41, Sada, Ed. O Castro.

González García, M. A. (1992-1993): "El entallador Benito Rodríguez Muxica y el retablo de la capilla de San Juan de la Catedral de Orense”, Porta da Aira: revista de bistoria del arte orensano, $\mathrm{n}^{\circ}$ 5, Ourense, pp. 95-122.

González García, M. A. (2010): "Santa Marta de Moreiras: obras pías, capellanías y cofradías (documentación en el archivo histórico diocesano de Ourense)”, Diversarum Rerum: revista de los Archivos Catedralicio y Diocesano de Ourense, $\mathrm{n}^{\circ}$ 5, Ourense, pp. 277-304.

Hervella Vázquez, J. (1996): “Escultura en Orense (1650-1698)”, Porta da Aira: revista de bistoria del arte orensano, $\mathrm{n}^{\circ} 7$, Ourense, pp. 5-28.

Leirós Fernández, E. (1951): Catálogo de los pergaminos monacales del Archivo de la S. I. Catedral de Orense, Santiago de Compostela, Ed. El Eco Franciscano.

Madoz, P. (1848): Diccionario geográfico-estadístico-histórico de España y sus posesiones de ultramar, t. XI, Madrid, p. 596.

"Moreiras, Santa Marta de" (1974), Gran Enciclopedia Gallega, t. XXI, Santiago de Compostela, p. 228.

Núñez Rodríguez, M. (1986): "Algunas reflexiones sobre el románico rural gallego", Boletín Académico. Escola Técnica Superior de Arquitectura da Coruña, A Coruña, Universidade da Coruña, pp. 4-9. 
Pérez Constanti, P. (1988): Diccionario de artistas que florecieron en Galicia durante los siglos XVI y XVII, Ed. Facs., Santiago de Compostela, Xunta de Galicia. Consellería da Presidencia e Administración Pública, Servicio Central de Publicacións, pp. 482-483.

Vázquez Núñez, A. (1961): "Documentos históricos. XXII. Privilegio de D. Alfonso V a favor del Monasterio de San Pedro de Rocas", Boletín de la Comisión Provincial de Monumentos Históricos y Artísticos de Orense, t. I, nº 19, Ourense, pp. 338-342.

\section{- FonTES}

ACO. Libro de visitas de los beneficios de este obispado de Orense, año de 1566 a 1569, en que era obispo el sr. D. Fernando Tricio de Arenzana, f. 165 v.

AHDO. Protocolo de Antonio Pérez de Araujo. 1690-1696. Caixa 600. Leg. 600.02., f. 149 r. v.; 150 r. e 151 r.

AHDO. Santa Marta de Moreiras. Libro de Fábrica 23.10.17 (1711-1876).

AHDO. Santa Marta de Moreiras. Libro de Fábrica 23.10.18 (1853-1940). 


\section{Anexos}

\section{Anexo documental}

Doc. 1. Solicitude de licenza para as obras da Capela Maior. AHDO. Santa Marta de Moreiras. Libro de Fábrica 32.10.17 (1711-1876) f. solto entre 62 v. 63 r.

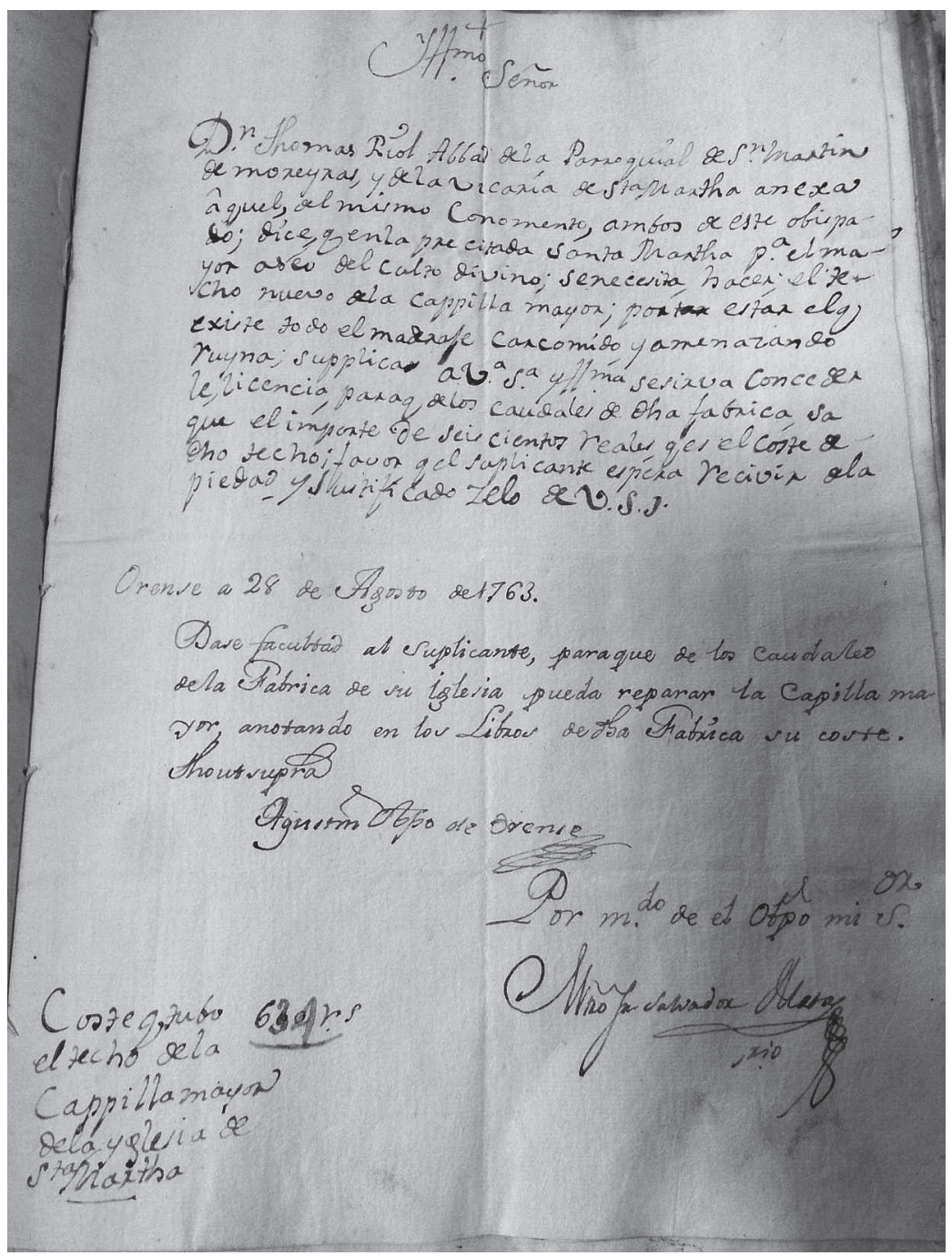


Doc. 2. Contas das obras da tribuna. 1747. AHDO. Santa Marta de Moreiras. Libro de Fábrica 32.10.17 (1711-1876) f. 45 v.

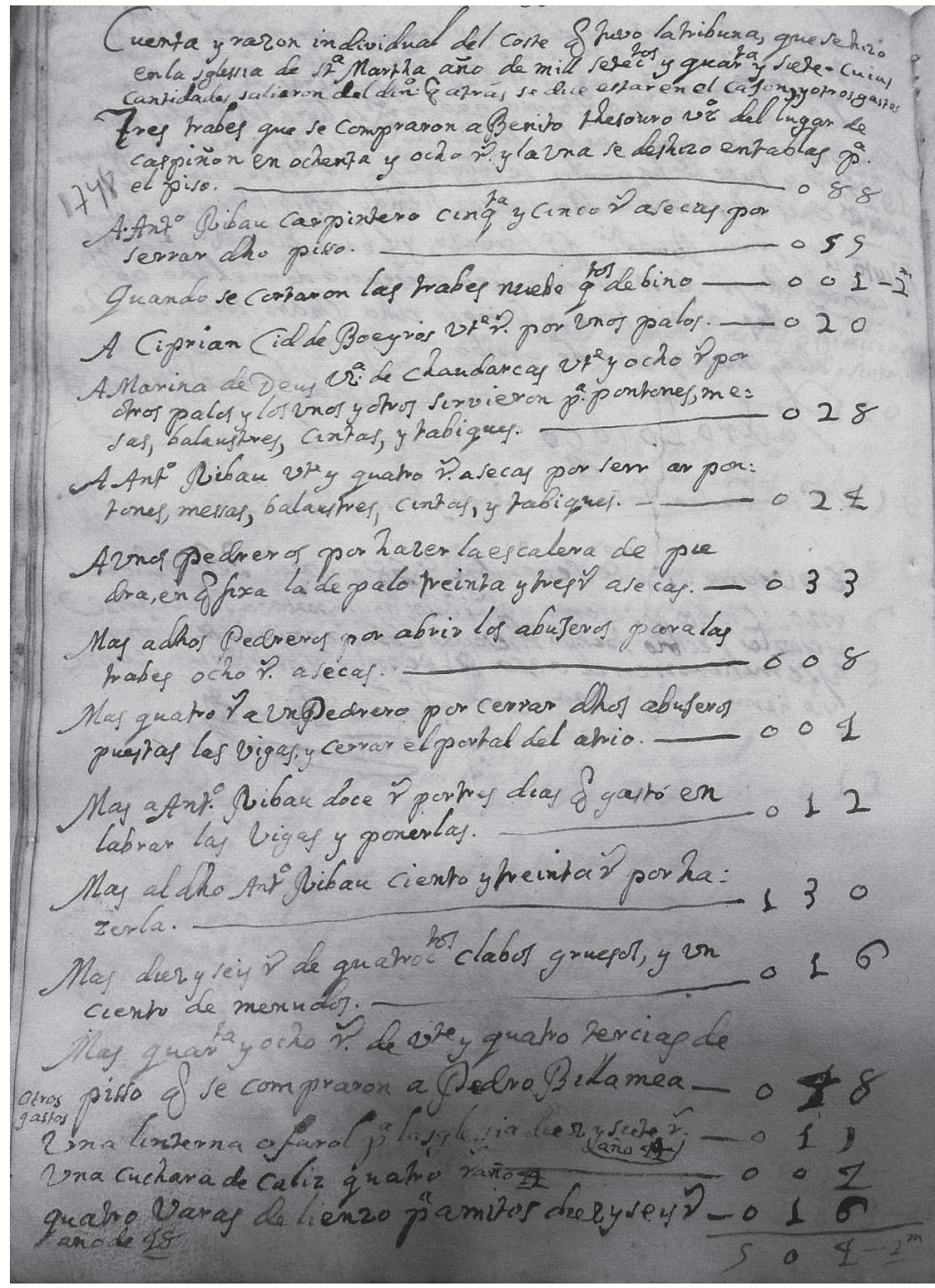


Doc. 3. Solicitude de licenza para a construcción do retablo maior. AHDO. Santa Marta de Moreiras. Libro de Fábrica 32.10 .17 (1711-1876) f. solto entre 56 v. 57 r.
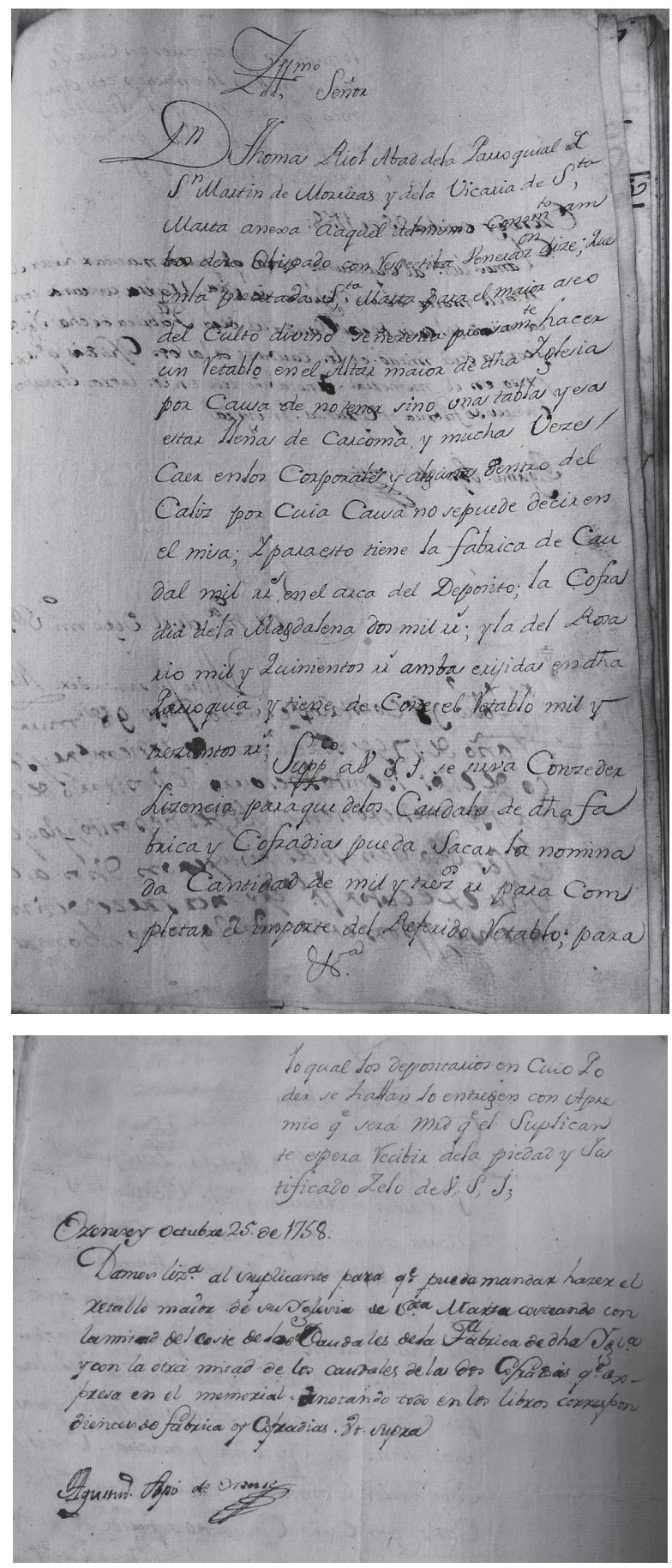
Doc. 4. Recibo da obra de Josef Oxea. AHDO. Santa Marta de Moreiras. Libro de Fábrica 32.10.17 (1711-1876) f. solto entre $72 \mathrm{v} .73 \mathrm{r}$.

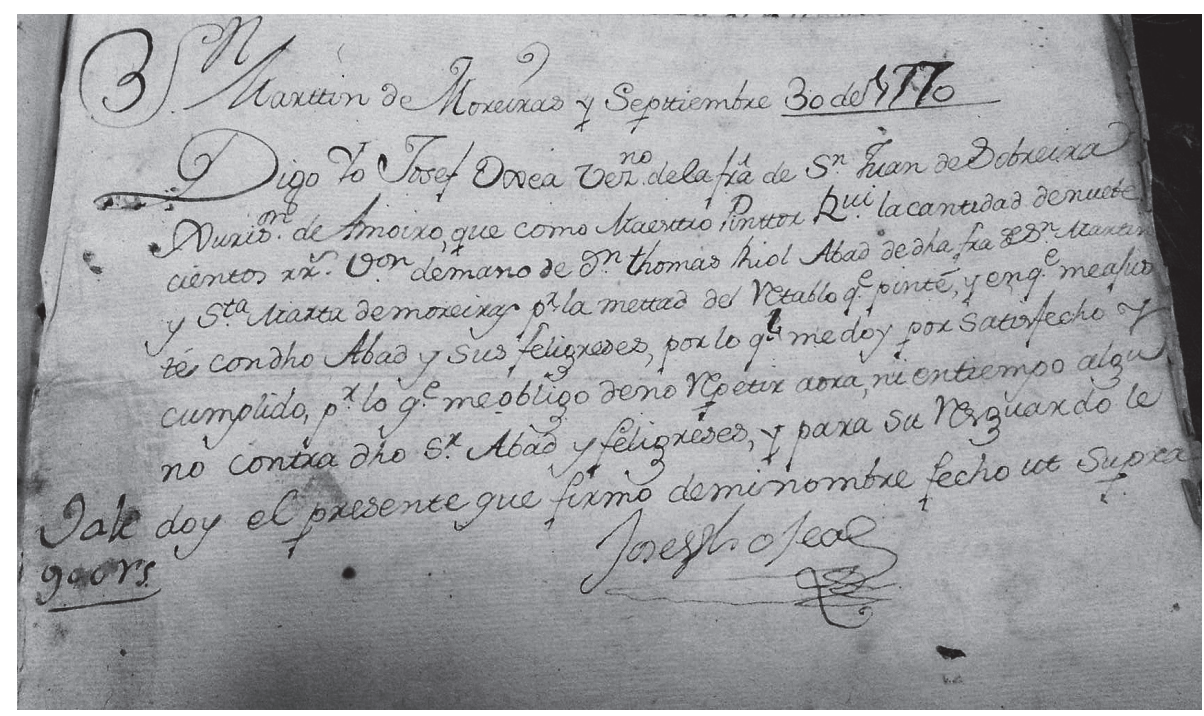

Doc. 5. Escritura sobre o axuste do retablo dos Gozos. FERNÁNDEZ OXEA, X. R. (1982): 91-93.

En 28 de Mayo de 1696.- Escritura de ajuste sobre la fábrica del retablo para Nuestra Señora de los Gozos.

En la ciudad de Orense y dentro de los Palacios episcopales de ella A veinte y ocho días del mes de Mayo de mil ss ${ }^{\circ}$ s y noventa y seis años ante mi escribano público y testigos lexitimamente Constituido el Sr. Licenciado D. Isidro de Valmaseda Provisor y Vicario General desa Ciudad y obispado y Juez de Obras Pias dixo que Por quanto los días pasados el Illustrisimo Sr. Obispo deste obispado y su md anydo a vistar personalmente con asistencia del presente escribano la hermita de Nuestra Señora de los Gozos sita en la feligresía de Santa Marta de Moreiras que dexo fundada Pedro Rodríguez Pantaleón, y rreconociendo se allava algo indecente por falta de retablo hallándose con imaxenes de mui relevante echura y veneración se acordó se fabricase uno de nuebo con quatro caxas Vna para el Santo Cristo, otra para Nuestra Señora y dos a los lados para san Pedro y Santo Domingo y se pagase su coste del caudal de $\mathrm{dh}^{\mathrm{a}}$ capilla y su obra pía. Y para que lo rreferido tubiese cumplido efecto con la maior brevedad dispuso su md. con Benito Rodríguez Muxica $\mathrm{Mr}^{\circ}$ entallador Vecino desta Ciudad el que fuese a reconocer el altar de $\mathrm{dh}^{\mathrm{a}}$ hermita su alto y ancho y formase la planta para hacer $\mathrm{dh}^{\circ}$ retablo. (...) = Primeramente $\mathrm{q}$ el $\mathrm{dh}^{\circ}$ Benito Muxica a de hacer $\mathrm{dh}^{\circ}$ retablo a reglándose $\mathrm{a} \mathrm{dh}^{\mathrm{a}}$ planta sin exceder haciéndole con las quatro caxas que arriba ban espesificadas y con los labores de carton y frutero y realçes Que manifiesta $\mathrm{dh}^{\mathrm{a}}$ planta. Y quatro columnas todas salomonicas y no triangulares $y$ a de tener mucho ancho y alto q espresa el 
pitipié q esta en $\mathrm{dh}^{\mathrm{a}}$ planta y en todo se a de a reglar a ella sin exceder de sus lavores antes si añadir los que fueren precisos para su mayor lucimiento sin que sea visto quedar obligado mas q a executarr $\mathrm{dh}^{\mathrm{a}}$ Planta $=$ y que a de ser de buena madera de nogal y castaño los rrespaldos de las caxas. Y que lo a de dar echo y acavado a satisfacción de personas peritas conforme a dh ${ }^{\mathrm{a}}$ planta dentro de seis meses siguientes a la fecha desta escritura puesto a su costa y llevantado en $\mathrm{dh}^{\mathrm{a}}$ hermita sin que para ello se le aia de dar cosa alguna mas de tan solamente dos pilastras de piedra $\mathrm{q}$ an de servir de pedestales y las fixas de hierro Para asegurarlo que esto lo a de pagar $\mathrm{dh}^{\mathrm{a}}$ obra pía $=$ Y que por raçon de $\mathrm{dh}^{\mathrm{a}}$ fabrica se le an de dar al sobre $\mathrm{dh}^{\mathrm{o}}$ Mill Reales de Vellon pagados en tres plaços los treçientos de ellos ahora de contado para comprar las maderas, treçientos en el medio de la fabrica y los quatroçientos restantes luego que fenesca y ponga en dicha hermita y en esta cantidad y en la forma referida tiene su md ajustado $\mathrm{dh}^{\mathrm{o}}$ retablo y cumpliendo con lo tratado obliga los vienes y Rentas de $\mathrm{dh}^{\mathrm{a}}$ hermita y su obra pía de dar y pagar y quedará y pagará Por mano del licenciado Rosendo Rodríguez su administrador $\mathrm{al} \mathrm{dh}^{\circ}$ Benito Rodríguez Muxica los dos mil reales de moneda de Vellon de a treinta y quatro mrs. cada uno a los tiempos y plaços q ban señalados de que constituie por deudora a $\mathrm{dh}^{\mathrm{a}}$ obra pía Cumpliendo el sobre $\mathrm{dh}^{\mathrm{o}}$ con su obligación y fabrica de $\mathrm{dh}^{\mathrm{o}}$ retablo según $\mathrm{dh}^{\mathrm{a}}$ planta Pena de que será compelido $\mathrm{dh}^{\mathrm{o}}$ administrador en nombre de $\mathrm{dh}^{\mathrm{a}}$ obra pía y de que se pagaran las costas y daños q se causaren = Presentes a todo lo referido el dh ${ }^{\circ}$ Benito Rodríguez Muxica que açetó y convino en este a juste y fabrica de $\mathrm{dh}^{\circ}$ retablo y en fuerça de el cumpliendo con lo que está de su parte se obliga en forma con su persona y vienes muebles y raíces havidas y por haver de haçer y fabricar el dh ${ }^{o}$ retablo según y en la forma que ba referido arreglándose a dh ${ }^{\mathrm{a}}$ planta en que está dibuxado la mitad de el sin que falte cosa alguna en sus lavores, ancho y largo de alto según el pitipié y medida que en ella está señalada dentro de los seis meses q se le ponen de término y lo pondrá en $\mathrm{dh}^{\text {a }}$ hermita a su costa comprando todas las maderas necesarias por quenta de dos Mill Rs. y en todo lo demás cumplirá con las calidades y condiciones desta escritura y executara dh ${ }^{\mathrm{a}}$ planta a satisfacción de maestros o personas Perictas pena q se hiciere o intentare haçer lo contrario quiere y consiente ser compelido executado y apremiado a ello or todo vigor de derecho Via sumaria o executiva y pagará todas las costas y daños q se causaren. En cuia conformidad ambas partes cada una por lo que le toca dan todo su poder cumplido y se someten a las justicias Eclesiasticas y seglares del fuero y Jurisdicción de juez competente pasada en cosa juzgada renuncia en todas leies de su favor la general y derechos della asimismo $\mathrm{dh}^{\circ}$ señor Provisor renuncio el capitulo obduardus suandepenis de solucionibus y las mas que le competen. Y asi otorgaron la presente Que firmaron de sus nombres estando a todo ello presentes por testigos Andrés Pérez Pedro Fernández y Don Manuel de Balterra familiar, de su Illma vecinos desta ciudad e yo escribano doi fee de ello y conozco los otorgantes.

$L d^{\circ}$ D. Isidro de Balmaseda (firmado y rubricado). - Benito Rodríguez (firmado y rubricado) En testmo Antonio Pérez. 
